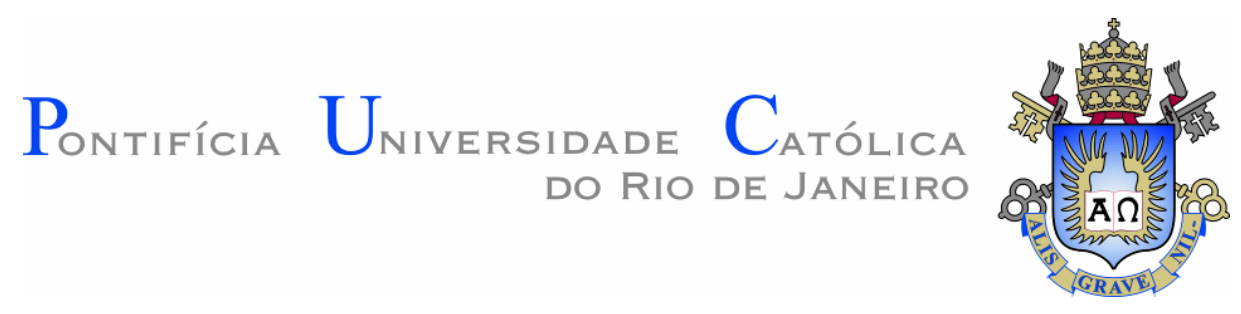

Thais de Sales Ribeiro

Poliedros de Arquimedes: um estudo enriquecedor para as aulas de geometria espacial na rede pública

Dissertação de Mestrado

Dissertação apresentada como requisito parcial para a obtenção do grau de Mestre pelo Programa de Pós-Graduação em Matemática do departamento de Matemática da PUC-Rio.

Orientador: Prof $\stackrel{0}{-}$ Marcos Craizer

Rio de Janeiro

Abril 2015 


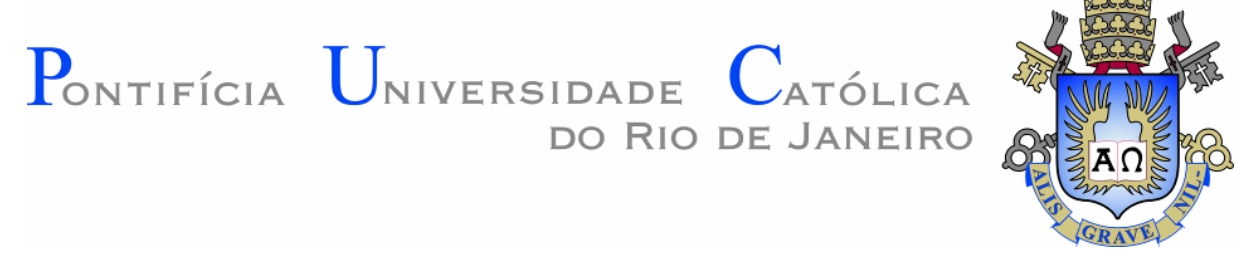

Thais de Sales Ribeiro

\section{Poliedros de Arquimedes: um estudo enriquecedor para as aulas de geometria espacial na rede pública}

Dissertação apresentada ao Programa de Pós-Graduação em Matemática da PUC-Rio como requisito parcial para a obtenção do grau de Mestre em Matemática. Aprovada pela Comissão Examinadora abaixo assinada.

Prof. Marcos Craizer

Orientador

Departamento de Matemática PUC-Rio

Profa. Christine Sertã Costa

Departamento de Matemática PUC-Rio

Profa. Dirce Uesu Pesco

Instituto de Matemática e Estatística

Departamento de geometria - UFF

Prof. Sinésio Pesco

Departamento de Matemática PUC-Rio

Prof. José Eugênio Leal

Coordenador Setorial do Centro Técnico Científico PUC-Rio

Rio de Janeiro, 09 de abril de 2015 
Todos os direitos reservados. É proibida a reprodução total ou parcial do trabalho sem autorização da universidade, do autor e do orientador.

\section{Thais de Sales Ribeiro}

Graduou-se em Licenciatura em Matemática pela UFF (Universidade Federal Fluminense) em 2010. Atua como professora de Ensino Fundamental e Médio na Secretaria Estadual de Educação do Rio de Janeiro.

\section{Ficha Catalográfica}

Ribeiro, Thais de Sales

Poliedros de Arquimedes : um estudo enriquecedor para as aulas de geometria espacial na rede pública / Thais de Sales Ribeiro ; orientador: Marcos Craizer. - 2015.

69 f. : il. (color.) ; $30 \mathrm{~cm}$

Dissertação (mestrado)-Pontifícia Universidade Católica do Rio de Janeiro, Departamento de Matemática, 2015.

Inclui bibliografia

1. Matemática - Teses. 2. Geometria. 3. Poliedros de Arquimedes. 4. Poliedros de Platão. 5. Ensino médio. 6. Rede pública. 7. Arte. I. Craizer, Marcos. II. Pontifícia Universidade Católica do Rio de Janeiro. Departamento de Matemática. III. Título. 


\section{Agradecimentos}

Agradeço primeiramente a Deus, por me fazer forte e me direcionar em todos os momentos.

A minha família e namorado, que compreenderam minhas horas de dedicação ao estudo.

Ao meu orientador Professor Marcos Craizer, pela dedicação e apoio.

A todos os professores do curso, que com toda a dedicação e conhecimento, contribuíram na minha formação profissional e pessoal.

Aos meus colegas de curso, que de forma especial contribuíram para que eu chegasse até aqui. E aproveito para dizer-lhes que é imenso o carinho que tenho por cada um deles.

A minha amiga Bruna Mayara, que Deus colocou no meu caminho de maneira muito especial, para unir forças nessa caminhada.

À Coordenação de Aperfeiçoamento de Pessoal de Nível Superior (CAPES) pela bolsa de estudos de mestrado.

Aos meus alunos que tanto se dedicaram nas etapas do desenvolvimento do trabalho.

As diretoras Margareth M. J. Mariano, Márcia Aparecida de C. R. Pestana e Sheila V. A. Dolejsi que me deram todo apoio necessário para desenvolver o trabalho na escola em que trabalhamos.

Aos amigos, colegas de trabalho e familiares que, de forma direta ou indireta, me ajudaram, apoiaram, compreenderam e torceram por mim. 


\section{Resumo}

Ribeiro, Thais de Sales; Craizer, Marcos. Poliedros de Arquimedes: um estudo enriquecedor para as aulas de geometria espacial na rede pública. Rio de Janeiro, 2015. 69p. Dissertação de Mestrado Departamento de Matemática, Pontifícia Universidade do Rio de Janeiro.

Este trabalho tem como eixo principal a inclusão do estudo dos Poliedros de Arquimedes, para complementar o conteúdo mínimo de geometria espacial, que é exigido para desenvolvimento desse conteúdo no ensino médio da rede publica de ensino. O trabalho foi desenvolvido de forma a valorizar o estudo de geometria, que apesar da sua extrema importância, vem perdendo espaço para a álgebra dentro do currículo mínimo, imposto pela Secretaria Estadual de Educação, e despertar no aluno o interesse pelo conteúdo a ser trabalhado. Dividido em três etapas, o desenvolvimento do trabalho iniciou-se com a planificação de poliedros, abrangendo o conceito de face, vértices e arestas, posições de reta e plano no espaço, construção de poliedros, poliedros regulares e semirregulares, visualização espacial, a relação de Euler e a demonstração do motivo pelo qual só existam cinco poliedros regulares. A utilização de recursos tecnológicos como ferramenta facilitadora no ensino, nesse primeiro momento, teve também como grande função, a busca da atenção e do interesse do aluno pelo conteúdo. A segunda e terceira etapas foram de exposição do trabalho desenvolvido, no primeiro momento, com intuito de, através da arte, expor de forma rápida e sucinta, quais são os poliedros de Platão, os Poliedros de Arquimedes e suas principais características, buscando alcançar um público além da sala de aula. $\mathrm{Na}$ terceira etapa, o aluno passa a ser o protagonista no desenvolvimento da oficina, que acontece simultaneamente à exposição do conteúdo através da arte.

\section{Palavras-chave}

Geometria; Poliedros de Arquimedes; Poliedros de Platão; ensino médio; rede pública; arte. 


\section{Abstract}

Ribeiro, Thais de Sales; Craizer, Marcos. Polyedra Archimedes: an enriching study for space geometry classes in the public schools. Rio de Janeiro, 2015. 69p. MSc.Dissertation - Departamento de Matemática, Pontifícia Universidade do Rio de Janeiro.

The main axis of this work is the inclusion of the study of "Polyhedra Archimedes "to complement the minimum content of space geometry, which is required for the development of this subject in high school at public schools. The work was developed to enhance the study of geometry, that despite its extreme importance has been losing ground for algebra within the minimum curriculum, imposed by the State Department of Education, and awaken in the student interest in the content to be worked. Divided into three stages, the development of the work started with the planning of polyhedra, including the concept of face, vertices and edges, straight positions and plane in space, construction of polyhedra, regular polyhedra and semiregular, spatial visualization, the Euler relationship and the demonstration of why there are only five regular polyhedra. The use of technological resources as an enabling tool for teaching, this first time, also had a great function, the pursuit of attention and interest of the student for the content. The second and third stages were exhibition of work at first with a view to, through art, expose quickly and succinctly, what are the polyhedra of Plato, the Polyhedra of Archimedes and its main features, seeking to reach an audience beyond the classroom. In the third stage, the student becomes the protagonist in the development of the workshop, held concurrently with the exhibition's content through art.

\section{Keywords}

Geometry; Polyhedra Archimedes; Polyhedra of Plato; high school; public school; art. 


\section{Sumário}

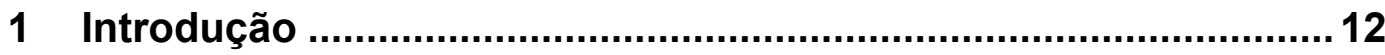

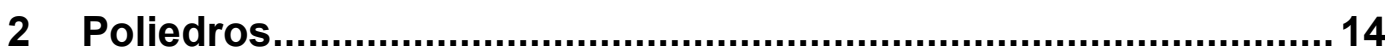

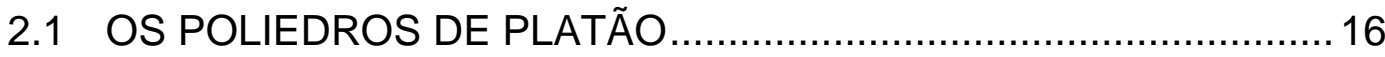

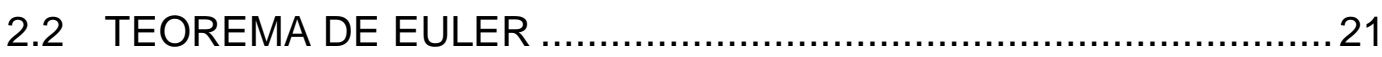

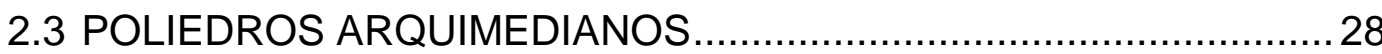

3 Os poliedros Arquimedianos a partir de truncaturas …................46

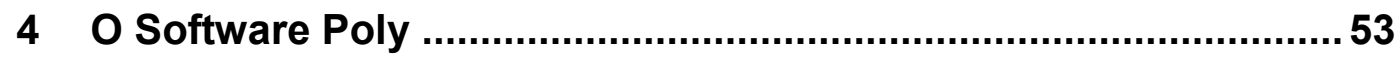

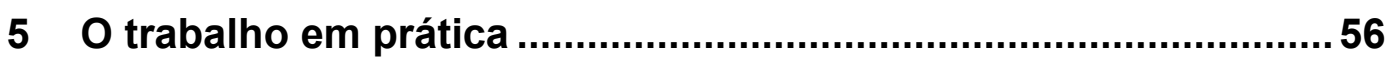

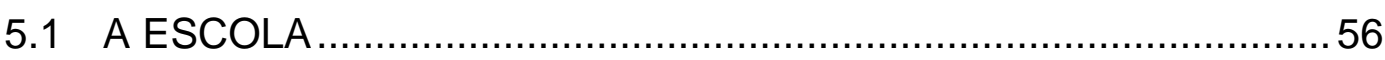

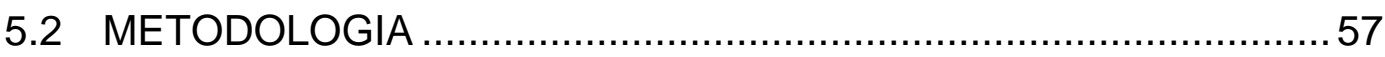

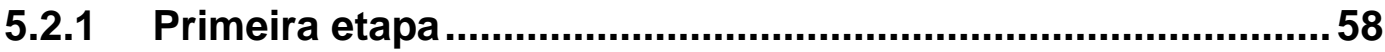

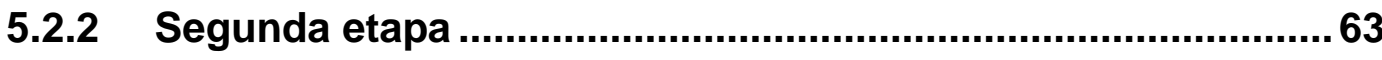

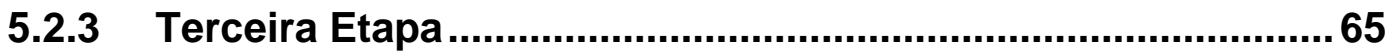

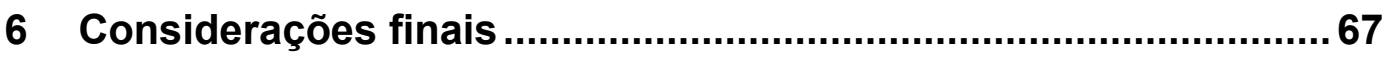

Referências Bibliográficas ..............................................................68 


\section{Lista de tabelas}

Tabela 1 - Poliedros com faces triangulares................................................... 20

Tabela 2 - Poliedros com faces quadrangulares. ................................................ 20

Tabela 3 - Poliedro com faces pentagonais. .................................................... 21

Tabela 4 - Possibilidades de poliedros formados por faces triangulares............... 26

Tabela 5 - Possibilidades de poliedros formados por faces quadrangulares. ........ 27

Tabela 6 - Possibilidades de poliedros formados por faces pentagonais............... 27

Tabela 7 - Ângulos internos de polígonos regulares. ........................................... 28

Tabela 8 - Número de faces, vértices e arestas do tetraedro e do tetraedro truncado.

Tabela 9 - Número de faces, vértices e arestas do cubo, cubo truncado e do cuboctaedro.

Tabela 10 - Número de faces, vértices e arestas do octaedro, e do octaedro truncado.

Tabela 11 - Número de faces, vértices e arestas do dodecaedro, dodecaedro truncado e do icosidodecaedro.

Tabela 12 - Número de faces, vértices e arestas do icosaedro e do icosaedro truncado.

Tabela 13 - Número de faces, vértices e arestas do cuboctaedro truncado e do rombicuboctaedro.

Tabela 14 - Número de faces, vértices e arestas do Icosidodecaedro truncado e do rombicosidodecaedro

Tabela 15 - 15 Número de faces, vértices e arestas do snub cuboctaedro e do snub icosidodecaedro 


\section{Lista de figuras}

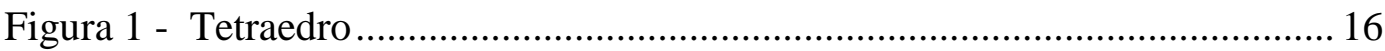

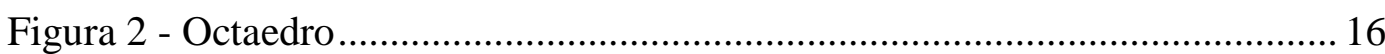

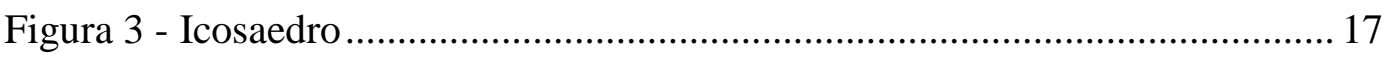

Figura 4 - Seis triângulos regulares, formando um hexágono regular................... 17

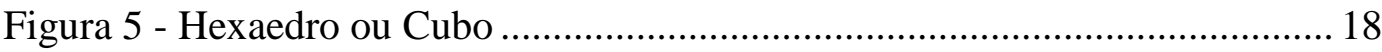

Figura 6 - Quatro quadrados concorrendo a um mesmo vértice........................... 18

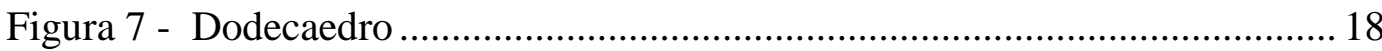

Figura 8 - Três pentágonos em torno de um mesmo vértice. ................................ 19

Figura 9 - Três hexágonos em torno de um mesmo vértice................................... 19

Figura 10 - O cubo e a projeção, no plano, dos pontos do seu contorno

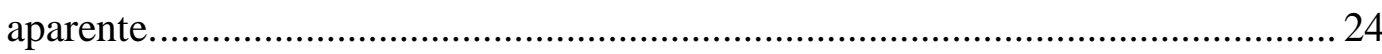

Figura 11 - Contorno das faces iluminadas e a projeção dos seus pontos no

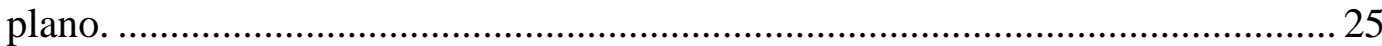

Figura 12 - Contorno das faces sombrias e a projeção dos seus pontos no

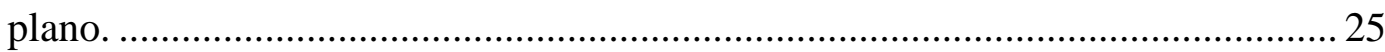

Figura 13 - Combinação impossível de quatro polígonos diferentes. ................... 28

Figura 14 - Vértice com três arestas concorrentes............................................... 29

Figura 15 - Combinação impossível de três polígonos, sendo um deles com

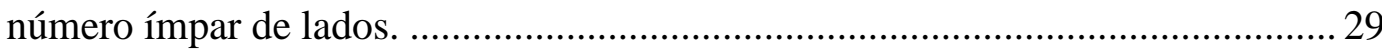

Figura 16 - Vértice com quatro arestas concorrentes. .......................................... 30

Figura 17 - Combinação de um triângulo, um pentágono e dois quadrados. ......... 30

Figura 18 - Combinação impossível pelo lema 2(ii)............................................ 31

Figura 19 - Vértice com três arestas concorrentes................................................. 31

Figura 20 - Antiprisma de base quadrada e sua planificação. ............................... 32

Figura 21 - Cubo achatado e sua planificação...................................................... 32

Figura 22 - Prisma de base triangular e sua planificação....................................... 33

Figura 23 - Vértice com dois triângulos e dois quadrados, dispostos em

$(3,4,3,4)$ e $(3,3,4,4)$ respectivamente, no sentido anti-horário 33

Figura 24 - Cuboctaedro e sua planificação. ......................................................... 34 
Figura 25 - Rombicuboctaedro e sua planificação. 34

Figura 26 - Antiprisma de base pentagonal e sua planificação. ............................. 35

Figura 27 - Snub Icosidodecaedro e sua planificação. 35

Figura 28 - Vértice com dois triângulos e dois pentágonos, dispostos em

$(3,5,3,5)$ e $(5,5,3,3)$ respectivamente, no sentido anti-horário. 36

Figura 29 - Icosidodecaedro e sua planificação.................................................... 36

Figura 30 - Antiprisma de base hexagonal e sua planificação. .............................. 37

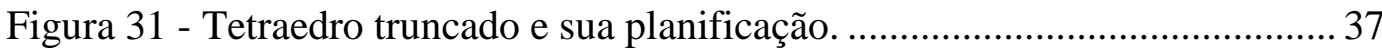

Figura 32 - Cubo truncado e sua planificação...................................................... 38

Figura 33 - Dodecaedro truncado e sua planificação. ............................................ 39

Figura 34 - Octaedro truncado e sua planificação. ............................................... 40

Figura 35 - Icosaedro truncado e sua planificação. ............................................. 41

Figura 36 - Dois triângulos, um quadrado e um polígono de $\boldsymbol{n}$ lados.................... 42

Figura 37 - Rombicosidodecaedro e sua planificação........................................ 42

Figura 38 - Cuboctaedro truncado ou grande rombicuboctaedro e sua planificação

Figura 39 - Icosidodecaedro truncado ou rombicosidodecaedro e sua

planificação 44

Figura 40 - Rombicuboctaedro e pseudorrombicuboctaedro. .............................. 45

Figura 41 - Tetraedro e tetraedro truncado......................................................... 46

Figura 42 - Cubo, cubo truncado e cuboctaedro................................................. 47

Figura 43 - Octaedro, octaedro truncado e cuboctaedro........................................ 48

Figura 44 - Dodecaedro, dodecaedro truncado e icosidodecaedro......................... 48

Figura 45 - Icosaedro, icosaedro truncado e icosidodecaedro.............................. 49

Figura 46 - Cuboctaedro, cuboctaedro truncado e rombicuboctaedro................... 50

Figura 47 - Icosidodecaedro, icosidodecaedro truncado e

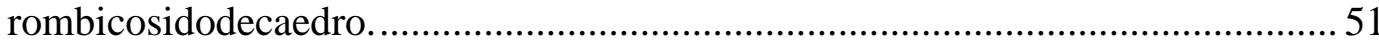

Figura 48 - Snub cuboctaedro e snub icosidodecaedro ........................................52

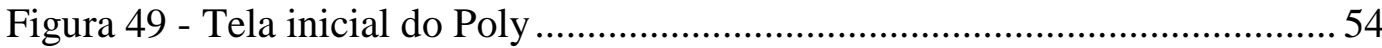

Figura 50 - Opções na barra de ferramentas........................................................ 54

Figura 51 - Etapas da transformação da visualização do poliedro em

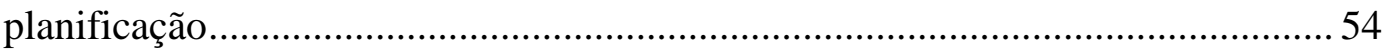

Figura 52 - Mais opções de visualização............................................................. 55 


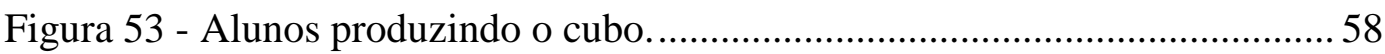

Figura 54 - Produção do esqueleto do tetraedro.................................................... 59

Figura 55 - Alunos produzindo poliedros Arquimedianos................................... 62

Figura 56 - Modelos da bola das Copas do Mundo de Futebol............................. 63

Figura 57 - Exposição do trabalho na Mostra Cultural da escola........................... 64

Figura 58 - O trabalho na Feira da Metropolitana II. .......................................... 65

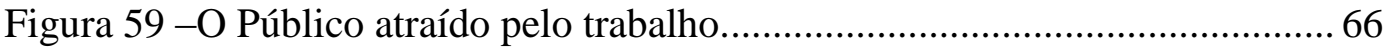




\section{INTRODUÇÃO}

Este trabalho foi pensado a partir da necessidade de levar a Matemática de forma atraente aos alunos, fazendo despertar em cada um deles o interesse pelo conteúdo a ser trabalhado.

A elaboração do desenvolvimento leva em consideração algumas problemáticas do cotidiano, em foco na rede pública de ensino, como por exemplo: alunos desinteressados e indisciplinados, limitações que os mesmos declaram ter, a defasagem de conteúdo de anos anteriores e o quantitativo do conteúdo de geometria espacial exigido pela Secretaria Estadual de Educação.

As dificuldades referentes ao ensino da Geometria tornam-se ainda maiores, pois de acordo com o currículo mínimo, o estudo de geometria espacial acontece apenas no segundo ano do ensino médio, um tempo muito curto para se desenvolver as habilidades e conteúdos cabíveis a esta matéria de grande importância.

De acordo com os Parâmetros Curriculares Nacionais (PCN), os conteúdos e habilidades a serem desenvolvidas em geometria espacial são:

Elementos dos poliedros, sua classificação e representação; Sólidos redondos; Propriedades relativas a posição: intersecção, paralelismo e perpendicularismo; Inscrição e circunscrição de sólidos.

- Usar formas geométricas espaciais para representar ou visualizar partes do mundo real, como peças mecânicas, embalagens e construções.

- Interpretar e associar objetos sólidos a suas diferentes representações bidimensionais, como projeções, planificações, cortes e desenhos.

- Utilizar o conhecimento geométrico para leitura, compreensão e ação sobre a realidade.

- Compreender o significado de postulados ou axiomas e teoremas e reconhecer o valor de demonstrações para perceber a Matemática como ciência com forma específica para validar resultados.

No entanto, os Parâmetros Curriculares Nacionais ainda afirmam que: 
Para desenvolver esse raciocínio de forma mais completa, o ensino de Geometria na escola média deve contemplar também o estudo de propriedades de posições relativas de objetos geométricos; relações entre figuras espaciais e planas em sólidos geométricos; propriedades de congruência e semelhança de figuras planas e espaciais; análise de diferentes representações das figuras planas e espaciais, tais como desenho, planificações e construções com instrumentos. (BRASIL, p. 123).

O uso do material concreto pode exercer um importante papel neste processo. Sendo assim, este trabalho tem como um dos principais objetivos, desenvolver o conteúdo de forma "palpável”, explorando o ensino através da observação da criação do próprio material de estudo.

Ana Maria Martensen Roland Kaleff afirma sobre o desenvolvimento da habilidade de visualização em nossa mente: "O desenvolvimento dessa habilidade acontece na medida em que se coloca para o aluno um apoio didático baseado em materiais concretos que representam o objeto geométrico de estudo." (KALEFF, 2008, p. 20).

O presente trabalho abrange o estudo dos Poliedros de Platão e dos Poliedros de Arquimedes, passando pela confecção de cada um deles, trabalhando as suas características e propriedades, explorando a visualização em três dimensões, fazendo relação com objetos cotidianos e observando regularidades e semelhanças. Para isso também foram utilizados recursos tecnológicos, como o programa Poly e o quadro interativo.

Desta maneira, o trabalho em foco tem o objetivo de mostrar um método facilitador do estudo dos Poliedros de Platão e dos Poliedros de Arquimedes através da construção dos mesmos, de projetos de exposição e oficina de criação. 


\section{POLIEDROS}

Este trabalho abordou o estudo de dois tipos de Poliedros: Os Poliedros de Platão e os Poliedros de Arquimedes, que fazem parte da classe dos convexos. Antes de conhecer melhor estes poliedros, é necessário que se defina polígonos, polígonos regulares e poliedros.

A palavra polígono é de origem grega que quer dizer muitos ângulos. Segue a definição dada por Osvaldo Dolce e José Nicolau:

Dada uma sequência de pontos de um plano $\left(A_{1}, A_{2}, \ldots, A_{n}\right)$ com $n \geq 3$, todos distintos, onde três pontos consecutivos não são colineares, considerando-se consecutivos $A_{n-1}, A_{n}$, assim como $A_{n}, A_{1}$ e $A_{2}$, chama-se polígono a reunião dos seguimentos $\overline{A_{1} A_{2}}, \overline{A_{2} A_{3}}, \ldots, \overline{A_{n-1} A_{n}}, \overline{A_{n} A_{1}}$. Os polígonos podem ser simples ou não. Um polígono é simples se, e somente se, a intercessão de quaisquer dois lados não consecutivos, é vazia. (DOLCE, 1997, p. 133).

Todo polígono simples é classificado em convexo ou não convexo, sendo o primeiro a característica necessária aos polígonos que formam as faces dos poliedros tratados aqui. Segue então a definição que convém ao estudo deste trabalho.

"Um polígono simples é convexo se, e somente se, a reta determinada por dois vértices consecutivos quaisquer deixa todos os demais $(n-2)$ vértices num mesmo semiplano que ela determina" (DOLCE, 1997, p.134)

Segue uma definição mais detalhada de polígonos convexos por Antônio Caminha Muniz Neto (2012, p.23):

Sejam $n \geq 3$ um natural e $A_{1}, A_{2}, \ldots, A_{n}$ pontos distintos do plano. Dizemos que $A_{1} A_{2} \ldots A_{n}$ é um polígono (convexo) se, para $1 \leq i \leq n$ a reta $A_{i} A_{i+1}$ não contém nenhum outro ponto $A_{j}$, mas deixa todos eles em um mesmo semiplano, dentre os que ela determina. Aqui e no que segue, $\left(A_{n}=A_{0}, A_{n+1}=\right.$ $A_{1}$ e $A_{n+2}=A_{2}$ ).

Vejamos, então, quando um polígono simples e convexo é regular: 
Um polígono que possui os lados congruentes é equilátero. Se possui os ângulos congruentes é equiângulo. Um polígono convexo é regular se, e somente se, tem todos os lados congruentes e todos os ângulos congruentes. (DOLCE, 1997, p.134)

De acordo com Lima et al. (2006, p.255) matemáticos de antigamente tiveram dificuldades em demonstrar teoremas sobre poliedros, pois não havia uma definição precisa desta palavra. E por esse motivo, ele recomenda apresentar, ao aluno do ensino médio, definições de poliedros suficientes para demonstrar teoremas e propriedades importantes. Não precisam ser, necessariamente, aquelas mais elaboradas matematicamente, que não permitem grandes generalidades. $\mathrm{O}$ volume 2 da coleção "A matemática do Ensino Médio" tem foco no estudo dos poliedros convexos e no conteúdo do ensino médio, e por esse motivo traz-se a definição que o autor apresenta:

Poliedro é uma reunião de um número finito de polígonos planos chamados faces onde:

- Cada lado de um desses polígonos é também lado de um, e apenas um, outro polígono;

- A interseção de duas faces quaisquer, ou é um lado comum, ou é um vértice ou é vazia;

- Cada lado de um polígono, comum a exatamente duas faces, é chamado uma aresta do poliedro e cada vértice de uma face é um vértice do poliedro;

- É sempre possível ir de um ponto de uma face, a um ponto de qualquer outra, sem passar por nenhum vértice (ou seja, cruzando apenas arestas).

“Um poliedro é convexo se qualquer reta (não paralela a nenhuma de suas faces) o corta em, no máximo dois pontos.” (LIMA, 2006, p.257).

Com as definições dadas acima, vamos nos aproximando do principal conteúdo de estudo deste trabalho: Os Poliedros Regulares e os Poliedros Semirregulares. 


\subsection{Os Poliedros de Platão}

Quando um poliedro convexo é composto por faces poligonais planas regulares do mesmo tipo, este poliedro também é dito regular. No entanto, se as faces que o compõe forem polígonos regulares de mais de um tipo, esse poliedro é chamado de semirregular.

Os poliedros regulares também são conhecidos como Poliedros de Platão. Segue uma definição dada por Lima (2006, p. 266) para esta classe de poliedros: "Um poliedro convexo é regular quando todas as faces são polígonos regulares iguais e em todos os vértices concorrem o mesmo número de arestas".

Vejamos os poliedros que possuem essas características:

\section{Tetraedro}
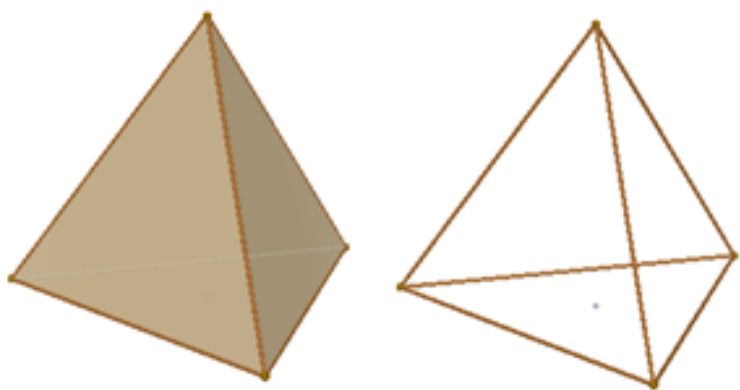

Figura 1 - Tetraedro Fonte: da autora

Possui quatro faces triangulares, seis arestas e quatro vértices, sendo três arestas concorrendo a cada um deles.

\section{Octaedro}
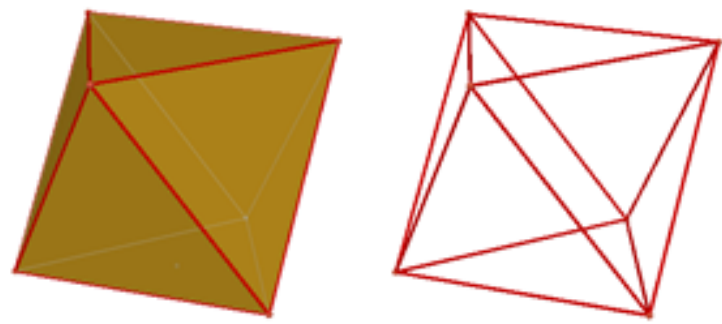

Figura 2 - Octaedro Fonte: da autora 
O Octaedro também é formado por faces triangulares, no entanto cada vértice possui quatro arestas concorrentes, uma a mais que no tetraedro. Sendo assim, ele é constituído por oito faces, doze arestas e seis vértices.

\section{Icosaedro}

O icosaedro por sua vez possui cinco arestas concorrendo a um mesmo vértice. Totalizando vinte faces triangulares, trinta arestas e doze vértices.
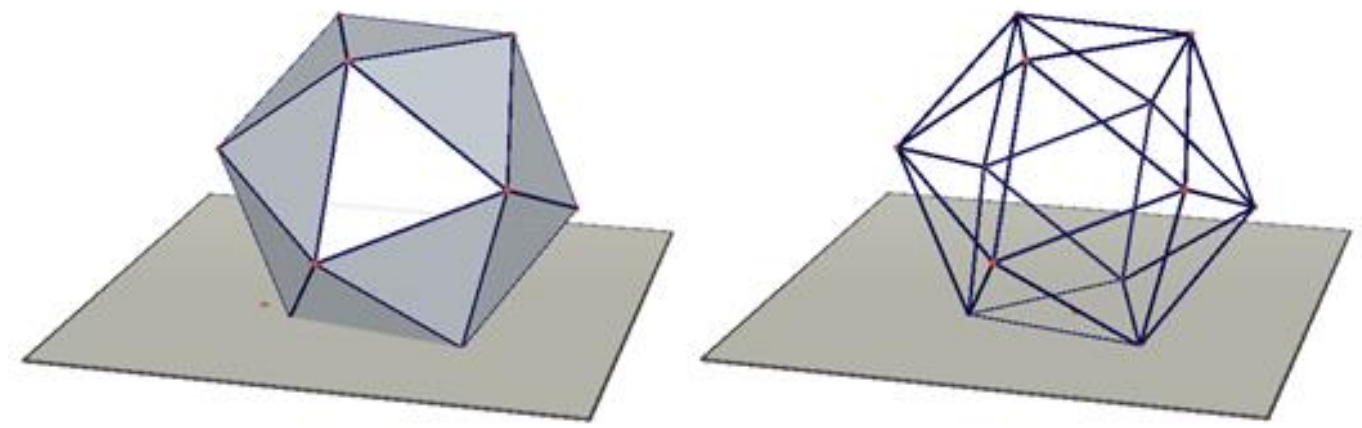

Figura 3 - Icosaedro

Fonte: da autora

Os poliedros regulares formados por faces triangulares encerram-se por aqui, pois se tivéssemos seis arestas concorrendo a um único vértice, teríamos os ângulos diédricos iguais a cento e oitenta graus, e na verdade formaria um novo polígono plano regular.

A união dos seis triângulos equiláteros resulta a soma de seis ângulos de sessenta graus em torno do vértice, totalizando trezentos e sessenta. Vejamos:

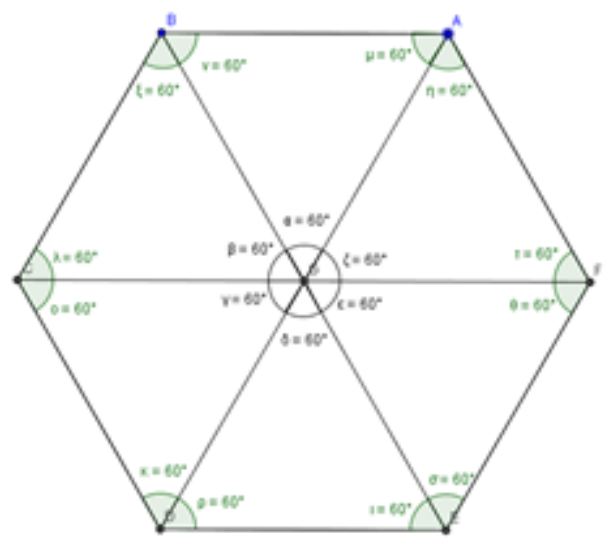

Figura 4 - Seis triângulos regulares, formando um Fonte: da autora hexágono regular. 


\section{Hexaedro (ou cubo)}
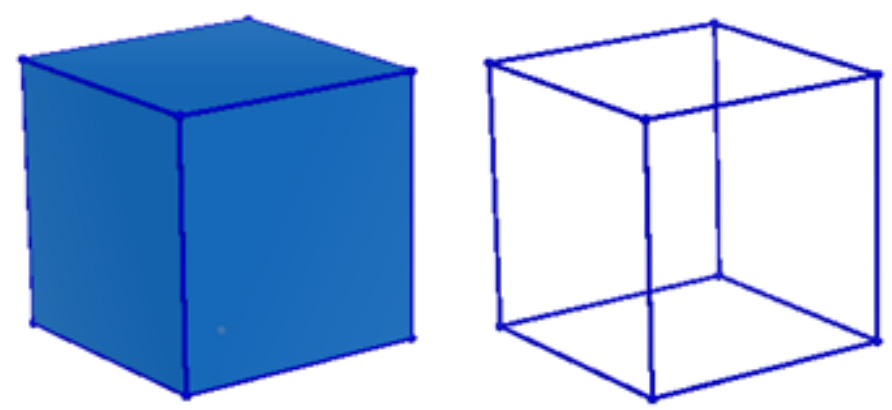

Figura 5 - Hexaedro ou cubo Fonte: da autora

O único poliedro regular formado por faces quadradas é o hexaedro, ou cubo, como também é conhecido. Com três arestas concorrendo a um mesmo vértice, ele possui um total de seis faces, doze arestas e oito vértices. Se em um único vértice concorressem quatro arestas teríamos novamente uma figura plana, como é apresentado abaixo:

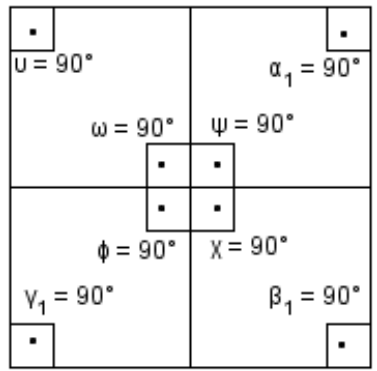

Figura 6 - Quatro quadrados em torno de um mesmo vértice.

Fonte: da autora

\section{Dodecaedro}
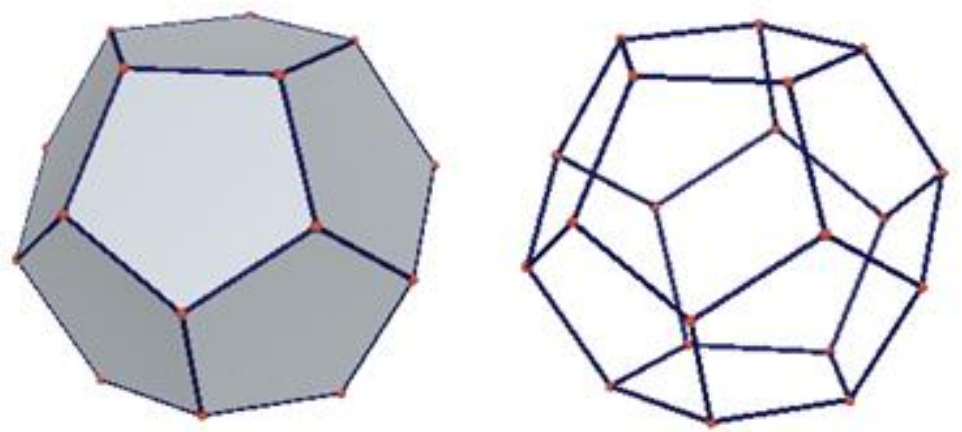

Figura 7 - Dodecaedro

Fonte: da autora 
O dodecaedro é o único poliedro regular formado por faces pentagonais, que totalizam doze. Possui vinte vértices e trinta arestas, concorrendo três em cada vértice. Não é possível formar um poliedro regular composto por pentágonos regulares com quatro ou mais arestas concorrendo a um mesmo vértice, pois os ângulos internos do mesmo medem cento e oito graus, sendo assim, não "caberiam" mais faces pentagonais regulares.

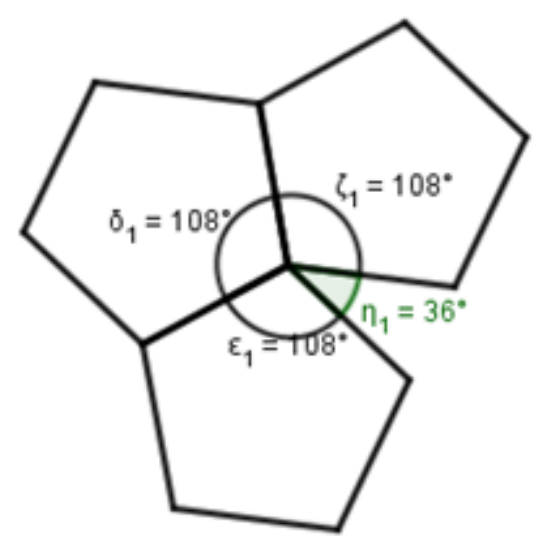

Figura 8 - Três pentágonos em torno de um mesmo vértice.

Fonte: da autora

O próximo passo seria construir um poliedro com faces hexagonais, no entanto, os ângulos internos deste polígono medem cento e vinte graus. Sendo assim, ao unir o mínimo de três faces poligonais, seu ângulo diédrico mede cento e oitenta graus, não sendo possível então, formar um novo poliedro. Dessa forma entende-se, que só existem os cinco poliedros regulares apresentados.

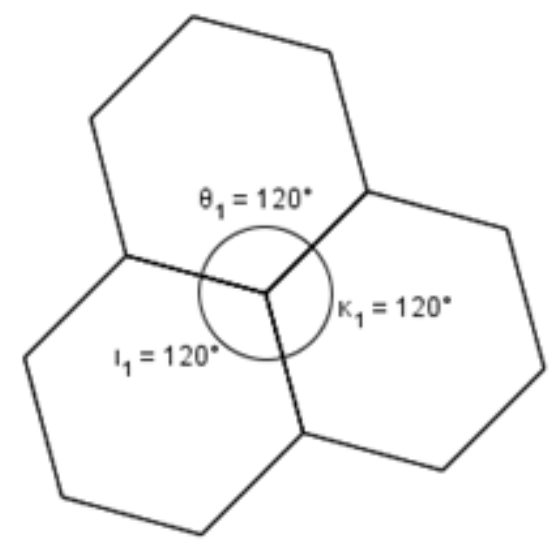

Figura 9 - Três hexágonos em torno mesmo vértice. Fonte: da autora 
Nessa ordem, foi produzido o material em sala, para que durante as construções já se tratasse de forma intuitiva a existência de apenas cinco poliedros regulares.

O professor Humberto José Bortolossi traz essa demonstração geométrica com base na proposição 21 do livro XI de Euclides, “Os Elementos". Para isso usa a seguinte propriedade:

“A soma dos ângulos dos polígonos em volta de cada vértice de um poliedro é sempre menor do que quatro ângulos retos." http://www.uff.br/cdme/platonicos/platonicos-html/solidos-platonicos-br.html

A demonstração é feita analisando as possibilidades de união das faces, lembrando que:

- $\quad$ Em um sólido platônico as faces são polígonos regulares congruentes;

- São necessárias pelo menos três faces unidas em cada vértice para formar um poliedro.

1 - As faces são triângulos equiláteros. Seus ângulos internos medem sessenta graus, assim temos as seguintes possibilidades:

Tabela 1 - Poliedros com faces triangulares.

\begin{tabular}{lll}
$\begin{array}{l}\text { Número de triângulos } \\
\text { equiláteros }\end{array}$ & Soma dos ângulos & Poliedro formado \\
\hline 3 & $3 \times 60^{\circ}=180^{\circ}$ & Tetraedro \\
4 & $4 \times 60^{\circ}=240^{\circ}$ & Octaedro \\
5 & $5 \times 60^{\circ}=300^{\circ}$ & Icosaedro \\
$\geq 6$ & $\geq 360^{\circ}$ & Não existe \\
\hline
\end{tabular}

Fonte: http://www.uff.br/cdme/platonicos/platonicos-html/solidos-platonicos-br.html

2- As faces são quadrados. Seus ângulos internos medem noventa graus, assim temos as seguintes possibilidades:

Tabela 2 - Poliedros com faces quadrangulares.

\begin{tabular}{ccc}
\hline Número de quadrados & Soma dos ângulos & Poliedro formado \\
\hline 3 & $3 \times 90^{\circ}=270^{\circ}$ & Hexaedro ou Cubo \\
$\geq 4$ & $\geq 360^{\circ}$ & Não existe \\
\hline
\end{tabular}

Fonte: http://www.uff.br/cdme/platonicos/platonicos-html/solidos-platonicos-br.html 
3 - As faces são pentágonos regulares. Seus ângulos internos medem cento e oito graus, assim temos as seguintes possibilidades:

Tabela 3 - Poliedro com faces pentagonais.

\begin{tabular}{ccc}
$\begin{array}{c}\text { Número de pentágonos } \\
\text { regulares }\end{array}$ & Soma dos ângulos & Poliedro formado \\
\hline 3 & $3 \times 108^{\circ}=324^{\circ}$ & Dodecaedro \\
$\geq 4$ & $\geq 432^{\circ}$ & Não existe \\
\hline
\end{tabular}

Fonte: http://www.uff.br/cdme/platonicos/platonicos-html/solidos-platonicos-br.html

Se as faces são polígonos regulares com $n \geq 6$ lados, então a soma dos ângulos dos polígonos em torno de cada vértice é $\geq 360^{\circ}$. Sendo assim, não existe nenhum sólido platônico com faces hexagonais, heptagonais, etc.

Baseado nesta demonstração, produziu-se o vídeo que ilustra as possibilidades analisadas acima. O vídeo esta disponível em https://www.youtube.com/watch?v=tjcbL6Rb4z8.

Outra demonstração para provar a existência de apenas cinco poliedros de Platão, não tanto intuitiva quanto a anterior, é apresentada mais a frente, pois ela depende da fórmula de Euler, que veremos a seguir.

\subsection{Teorema de Euler}

Durante os encontros que ocorreram na escola, como parte do desenvolvimento deste trabalho, os alunos montaram poliedros e fizeram anotações referentes ao número de faces, vértices e arestas dos mesmos. E com auxílio deste material produzido, foram trabalhadas algumas relações antes da utilização da relação de Euler para poliedros convexos.

Da definição de poliedros, temos que o lado de um polígono pertence a apenas um único outro polígono, ou seja, uma única aresta pertence a duas faces desse poliedro, e cada aresta possui em cada uma de suas extremidades um vértice. Então, chegar à compreensão da relação do número de arestas com o número de faces, fica mais simples com a observação das planificações dadas em aula. Assim como a relação do número de arestas com o número de vértices.

Considere $A$ o número de arestas, $F$ o número de faces e $V$ o número de vértices. Como um poliedro pode ou não possuir mais de um tipo de face, considere por $F_{n}$ o número de faces que possui $n$ lados. Os vértices de um 
poliedro também podem variar em número de arestas concorrentes, então considere $V_{n}$ o número de vértices com $n$ arestas.

Daí tem-se que:

$$
\begin{gathered}
F=F_{3}+F_{4}+F_{5}+\cdots \\
V=V_{3}+V_{4}+V_{5}+\cdots
\end{gathered}
$$

Com a planificação do poliedro em mãos o aluno pode verificar quantas faces triangulares ele possui e multiplicar por três, que é o número de lados desse polígono, quantas faces quadrangulares e multiplicar por quatro, e assim sucessivamente. Dessa forma, ao somar esses valores tem-se o dobro do número de arestas. Logo,

$$
2 A=3 F_{3}+4 F_{4}+5 F_{5}+\cdots
$$

Para a relação entre o número de arestas e o número de vértices, a melhor observação é com o poliedro já montado. Assim, o aluno verifica quantos vértices ele possui e quantas arestas concorrem a cada um deles.

A soma do número de arestas concorrendo a um mesmo vértice multiplicado pelo número de vértices também resultará no dobro do número de arestas, pois a mesma será contada duas vezes, visto que cada uma possui dois vértices, um em cada extremidade. Sendo assim,

$$
2 A=3 V_{3}+4 V_{4}+5 V_{5}+\cdots
$$

Vale lembrar, que a intenção não é fazer o aluno ficar contando vértices, faces e arestas. É utilizar o material como instrumento facilitador na compreensão dessas relações.

O Professor Zoroastro Azambuja Filho, em uma publicação que fez na Revista do Professor de Matemática (RPM), diz que por muitas vezes demonstrou a fórmula de Euler para poliedros a seus alunos, achando que estava fazendo da maneira correta. Até que descobriu através do artigo "O teorema de Euler sobre poliedros", publicado pelo professor Elon Lages Lima, que os argumentos usados, não eram suficientes.

Zoroastro compreende a correção para a "demonstração de Cauchy" sugerida por Elon. No entanto, ele busca uma demonstração particular, válida apenas para poliedros convexos, sugerida por Elon neste mesmo artigo e publica essa demonstração na terceira edição da RPM (Revista do Professor de 
Matemática) em 1983, de forma que julga mais acessível à compreensão de seus alunos.

Elon, então, volta a publicar esta demonstração de Zoroastro no livro "A matemática do ensino médio, volume 2", que é apresentada a seguir:

Teorema (Euler): Em todo poliedro de $A$ arestas, $V$ vértices e $F$ faces, vale a relação $V-A+F=2$.

Demonstração: Iniciamos a demonstração calculando a soma dos ângulos internos de todas as faces de um poliedro convexo $P$. As faces são numeradas de 1 até $F$ e seja $n_{k}$ o gênero da $k$-ésima face $(1 \leq k \leq F)$. Lembrando que a soma dos ângulos internos de um polígono convexo de gênero $n$ é igual a $\pi(n-2)$ e observando que, se um poliedro é convexo, então, todas as suas faces são polígonos convexos, teremos para a soma dos ângulos internos de todas as faces de $P$ a expressão:

$$
S=\pi\left(n_{1}-2\right)+\pi\left(n_{2}-2\right)+\cdots+\pi\left(n_{f}-2\right) .
$$

Ou ainda,

$$
S=\pi\left[\left(n_{1}+n_{2}+\cdots+n_{f}\right)-(2+2+\cdots 2)\right] .
$$

Temos que:

$\left(n_{1}+n_{2}+\cdots+n_{f}\right)$ é a soma dos lados de todas as faces, ou seja, é igual ao dobro do número de arestas.

$(2+2+\cdots 2)$ é a soma de $F$ parcelas iguais a 2 que tem como resultado $2 F$.

$$
\begin{aligned}
& \text { Assim, } S=\pi(2 A-2 F)= 2 \pi(A-F) \\
& \frac{S}{2 \pi}=(A-F)
\end{aligned}
$$

Vamos agora escolher uma reta $r$ que não seja paralela a nenhuma das faces de $P$. Tomamos também um plano $H$, que não intercepta $P$ e que seja perpendicular a $r$. O plano $H$ será chamado plano horizontal e as retas paralelas a $r$ (logo, perpendiculares a $H$ ) serão chamadas retas verticais. $\mathrm{O}$ plano $H$ divide o espaço em dois semiespaços, um dos quais contém o poliedro $P$. Este será chamado de semiespaço superior e diremos que seus pontos estão acima de $H$. Para melhor ilustrar nosso raciocínio, imaginaremos o sol brilhando a pino sobre o semiespaço superior de modo que seus raios sejam retas verticais. Cada ponto $X$ do semiespaço superior corresponde a um ponto $X^{\prime}$ em $H$, chamado sombra de $X$. 
A sombra de qualquer conjunto $C$, contido no semiespaço superior é, por definição, o conjunto $C$, contido em $H$, formado pelas sombras dos pontos de $C$.
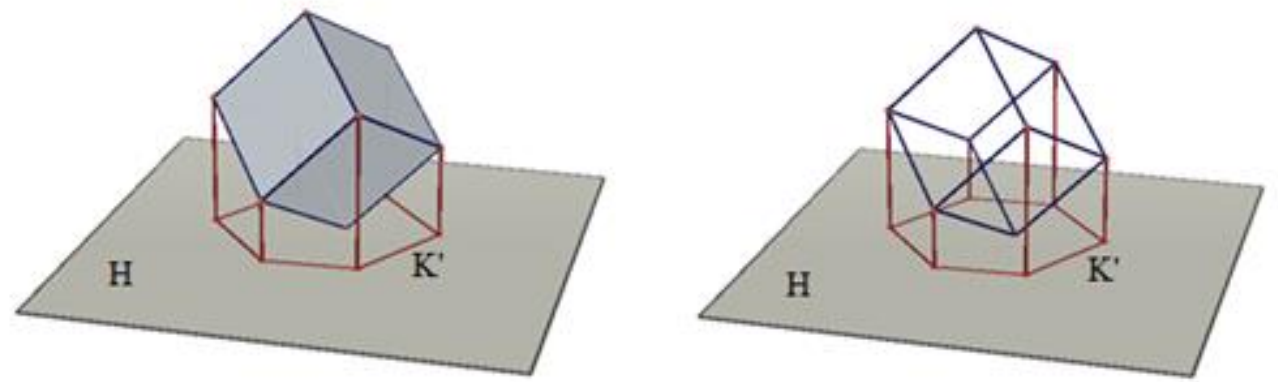

Figura 10 - O cubo e a projeção, no plano, dos pontos do seu contorno Fonte: da autora aparente.

Consideremos então, a sombra $P^{\prime}$ do poliedro $P$. Como $P$ é convexo, cada ponto de $P^{\prime}$ é sombra de um ou dois pontos de $P$ (de acordo com a definição de poliedro convexo dada anteriormente). Ora, a sombra $P^{\prime}$ do poliedro $P$ tem como contorno um polígono convexo $K^{\prime}$, sombra de uma poligonal fechada $K$ formada por arestas de $P$. Cada ponto de $K^{\prime}$ é sombra de um único ponto de $P$. A poligonal $K$ é chamada de contorno aparente do poliedro $P$. Cada ponto interior de $P^{\prime}$ (portanto não pertence a $K^{\prime}$ ) é sombra exatamente de dois pontos de $P$. Dados dois pontos de $P$ que tem a mesma sombra, ao mais alto (mais distante de $H$ ) chamaremos de ponto iluminado e o mais baixo será chamado de sombrio.

Depois dessas considerações, vamos calcular novamente a soma de todos os ângulos das faces de $P$, observando que a soma dos ângulos internos de uma face é a mesma soma dos ângulos internos de sua sombra (ambos são polígonos do mesmo gênero). Sejam $V_{1}$ o número de vértices iluminados, $V_{2}$ o número de vértices sombrios e $V_{0}$ o número de vértices do contorno aparente $K$. Então $V=V_{0}+V_{1}+V_{2}$. Notemos ainda que $V_{0}$ é o número de vértices (e de lados) da poligonal $K^{\prime}$, contorno de $P^{\prime}$. Consideremos então o contorno das faces iluminadas. 


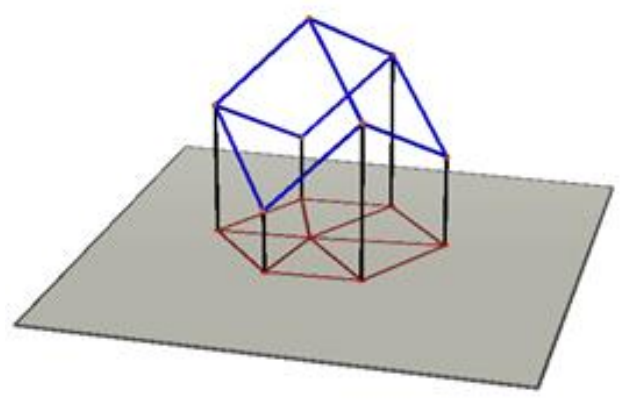

Figura 11 - Contorno das faces iluminadas e a projeção Fonte: da autora dos seus pontos no plano.

A sombra das faces iluminadas é um polígono convexo com $V_{0}$ vértices em seu contorno e $V_{1}$ pontos interiores, sombra dos vértices iluminados de $P$. A soma de todos os ângulos da figura anterior é:

$$
S_{1}=2 \pi V_{1}+\pi\left(V_{0}-2\right) .
$$

Por raciocínio inteiramente análogo, obteríamos, para a soma de todos os ângulos da soma das faces sombrias, $S_{2}=2 \pi V_{2}+\pi\left(V_{0}-2\right)$.

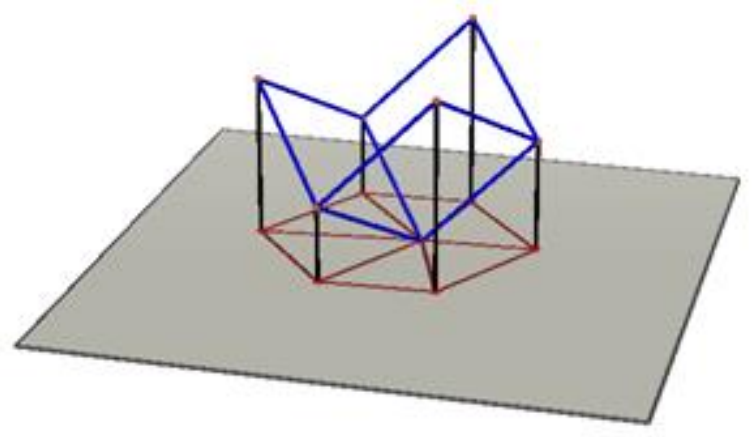

Figura 12 - Contorno das faces sombrias e a projeção dos seus pontos no plano.

Fonte: da autora

Somando as duas, obtemos:

$$
\begin{gathered}
S=2 \pi V_{1}+2 \pi V_{2}+2 \pi\left(V_{0}-2\right) \\
S=2 \pi\left(V_{1}+V_{2}+V_{0}-2\right) \\
S=2 \pi(V-2) \\
\frac{S}{2 \pi}=(V-2)
\end{gathered}
$$

Igualando $\frac{S}{2 \pi}=(V-2) \operatorname{com} \frac{S}{2 \pi}=(A-F)$ resulta

$$
V-2=A-F
$$


Ou $V+F=A+2$ como costuma ser apresentada nos livros de ensino médio.

Vista a relação de Euler, será apresentada uma segunda demonstração da existência de apenas cinco poliedros regulares convexos.

Teorema: Existem apenas cinco poliedros regulares convexos.

Demonstração: Seja $n$ o número de lados de cada face e seja $p$ o número de arestas que concorrem em cada vértice. Temos, então,

$$
2 A=n F \text { e } 2 A=p V .
$$

Substituindo na relação de Euler, obtemos:

$$
\begin{gathered}
\frac{n F}{p}-\frac{n F}{2}+F=2 \\
2 n F-p n F+2 p F=4 p \\
F(2 n-p n+2 p)=4 p \\
F=\frac{4 p}{2 n-p n+2 p} .
\end{gathered}
$$

Devemos ter $2 n-p n+2 p>0$, ou seja,

\begin{tabular}{|c|c|c|c|}
\hline \multirow{3}{*}{$n=3$} & \multirow{3}{*}{$F=\frac{4 p}{6-3 p+2 p}$} & $p=3 \rightarrow F=4$ & Tetraedro \\
\hline & & $p=4 \rightarrow F=8$ & Octaedro \\
\hline & & $p=5 \rightarrow F=20$ & Icosaedro \\
\hline
\end{tabular}

$$
\begin{gathered}
2 n>p n-2 p \\
2 n>p(n-2) \\
\frac{2 n}{n-2}>p
\end{gathered}
$$

Como o número de arestas concorrendo a um mesmo vértice deve ser maior que três, temos as seguintes possibilidades:

Tabela 4 - Possibilidades de poliedros formados por faces triangulares.

Fonte: (LIMA et. all, 2006, p. 267)

Se $p=6$ teremos $\frac{2 \times 3}{3-2}=6=p$, não atendendo a desigualdade $\frac{2 n}{n-2}>p$, ou seja, só existem três poliedros regulares formados por faces triangulares. 
Tabela 5 - Possibilidades de poliedros formados por faces quadrangulares.

$$
\begin{array}{llll} 
& \boldsymbol{F}=\frac{\mathbf{2 p}}{\mathbf{4 - \boldsymbol { p }}} & p \geq 4 \rightarrow \frac{2 n}{n-2} \leq p & \text { Hexaedro } \\
\cline { 3 - 4 } & & &
\end{array}
$$

Fonte: (LIMA et. all, 2006, p. 267)

Tabela 6 - Possibilidades de poliedros formados por faces pentagonais.

\begin{tabular}{llll}
$n=5$ & $\boldsymbol{F}=\frac{\mathbf{4} \boldsymbol{p}}{\mathbf{1 0 - 3 p}}$ & $p \geq 4 \rightarrow \frac{2 n}{n-2} \leq p$ & Dodecaedro \\
\cline { 3 - 4 } & &
\end{tabular}

Fonte: (LIMA et. all, 2006, p. 267) 


\subsection{Poliedros Arquimedianos}

Os poliedros de Arquimedes também são conhecidos como poliedros semirregulares. No entanto, existem infinitos poliedros semirregulares.

De acordo com Peter Cromwell (1997), Kepler define os poliedros semirregulares como aqueles que possuem vértices similares, ou seja, todos com a mesma disposição de polígonos, e faces regulares de mais de um tipo. Ele também os chama de poliedros perfeitos a um menor grau e os subdivide em Arquimedianos e Imperfeitos (prismáticos).

Kepler verificou todas as maneiras possíveis de se agrupar polígonos regulares em torno de um vértice, de maneira a se formar poliedros semirregulares, como veremos a seguir:

Lema 1: Se todas as faces de um poliedro convexo são polígonos regulares, então, no máximo três tipos diferentes de faces podem aparecer em torno de qualquer ângulo sólido.

Se combinarmos quatro a quatro diferentes polígonos regulares, teremos sempre a soma de seus ângulos internos maiores que $360^{\circ}$. Vejamos essa combinação com os quatro menores ângulos internos de polígonos regulares:

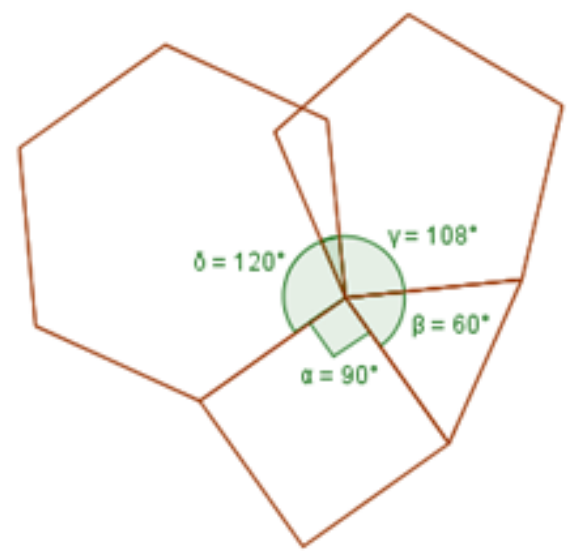

Figura 13 - Combinação impossível de quatro polígonos diferentes.

Fonte: da autora

Tabela 7 - Ângulos internos de polígonos regulares.

\begin{tabular}{ccccc}
\hline $\begin{array}{c}\text { Ângulo } \\
\text { interno de um } \\
\text { triângulo }\end{array}$ & $\begin{array}{c}\text { Ângulo } \\
\text { interno de um } \\
\text { quadrado }\end{array}$ & $\begin{array}{c}\text { Ângulo interno } \\
\text { de um } \\
\text { pentágono }\end{array}$ & $\begin{array}{c}\text { Ângulo interno } \\
\text { de um } \\
\text { hexágono }\end{array}$ & Total da soma \\
\hline $60^{\circ}$ & $90^{\circ}$ & $108^{\circ}$ & $120^{\circ}$ & $378^{\circ}$ \\
\hline
\end{tabular}

Fonte: da autora 
Assim, verificamos facilmente que, para quaisquer outros quatro diferentes polígonos regulares essa soma será maior que $360^{\circ}$.

Lema 2: Um poliedro em que todos os ângulos sólidos estão rodeados da mesma maneira não pode ter ângulos sólidos se:

(i) $\quad a$ é impar e $b \neq c$, onde $a, b$ e $c$ é o número de lados dos polígonos em torno do vértice.

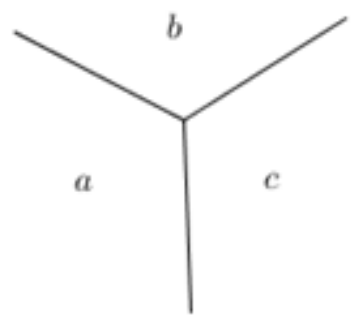

Figura 14 - Vértice com três arestas concorrentes. Fonte: da autora

Suponha $a=3 ; b=4$ e $c=5$, temos então um triângulo, um quadrado e um pentágono. O triângulo por sua vez deve estar rodeado pelos polígonos de lado $\mathrm{b}$ e $\mathrm{c}$, com $\mathrm{b} \neq \mathrm{c}$. Como todos os vértices devem ter o mesmo arranjo de polígonos, neste caso não será possível, vejamos:
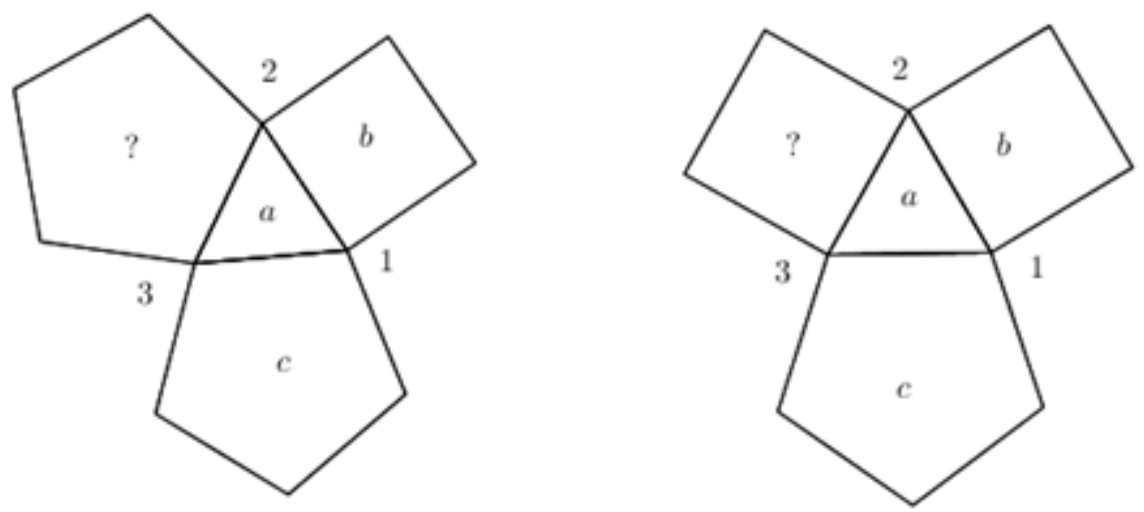

Figura 15 - Combinação impossível de três polígonos, sendo um deles com número ímpar de lados.

Fonte: da autora

Observe que o vértice 1 é composto pelos polígonos de lados $a, b$ e $c$, no entanto, nos vértices 2 e 3 não será possível obter essa semelhança, pois teremos ou um desses vértices formados por um triângulo e dois quadrados ou um 
triângulo e dois pentágonos. Logo, não é possível formar poliedros com essa disposição de polígonos.

(ii) $\quad$ Se $a \neq c$;

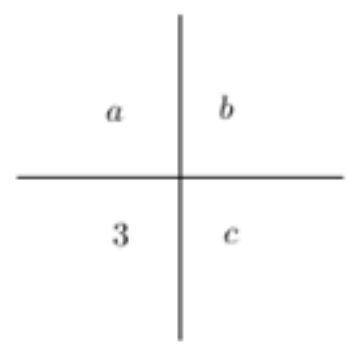

Figura 16 - Vértice com quatro arestas Fonte: da autora

Se $a \neq b \neq c \neq 3$ pelo lema 1 já podemos concluir que não existe poliedros com essa disposição de polígonos em torno de um vértice.

Vejamos então que não é possível tal disposição. Como o lema 1 já descarta a possibilidade quando $a \neq b \neq c \neq 3$, suponha $a=5$ e $b=c=4$.

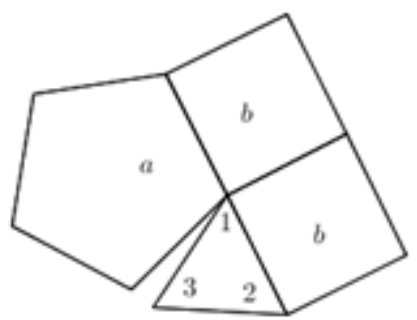

Figura 17 - Combinação de um triângulo, um Fonte: da autora

Observe o vértice 1 , rodeado por um triângulo, um pentágono e dois quadrados. O vértice 2, deve seguir a mesma formação, tendo um quadrado oposto ao triângulo, vejamos: 


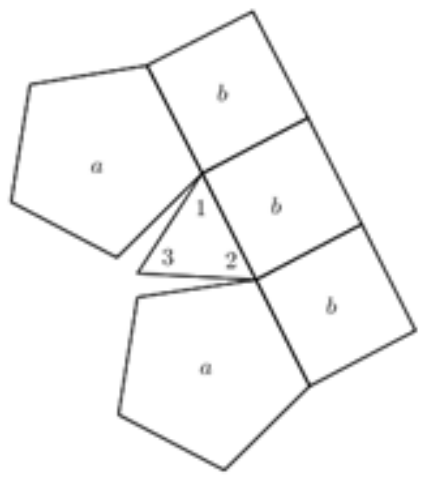

Figura 18 - Combinação impossível pelo lema 2(ii). Fonte: da autora

No entanto, essa mesma formação não é possível no vértice 3, pois o triângulo teria dois pentágonos, um em cada uma de suas laterais e um quadrado oposto ao vértice 3 .

Pela definição de poliedro semirregular, temos que cada ângulo sólido deve apresentar no mínimo dois tipos de polígonos distintos.

Vejamos inicialmente todas as combinações possíveis para um ângulo sólido com apenas dois tipos de polígonos:

\section{1) Ângulos sólidos formados por triângulos e quadrados:}

a. Um quadrado e um triângulo

É preciso de, no mínimo, três polígonos para formar um ângulo sólido, logo essa combinação é obviamente inválida.

b. Um quadrado e dois triângulos

Verifica-se pelo lema 2(i) que não é possível formar ângulos sólidos com essa combinação de polígonos. Onde $a=3$ é impar e $b=3 \neq c=4$.

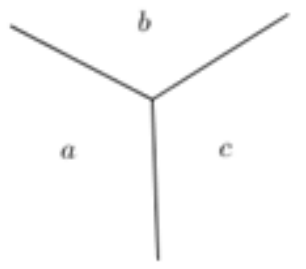

Figura 19 - Vértice com três arestas concorrentes.

Fonte: da autora

c. Um quadrado e três triângulos

Com essa disposição tem-se um antiprisma quadrangular, com um total de duas faces quadradas, oito faces triangulares, dezesseis arestas e oito vértices. 

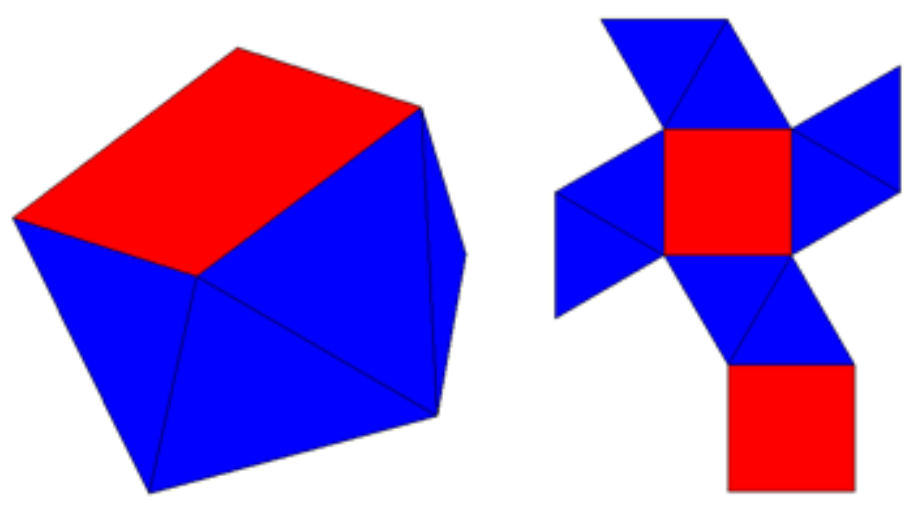

Figura 20 - Antiprisma de base quadrada e sua planificação. Fonte: da autora

d. Um quadrado e quatro triângulos

Tem-se o cubo achatado ou snub cuboctaedro.
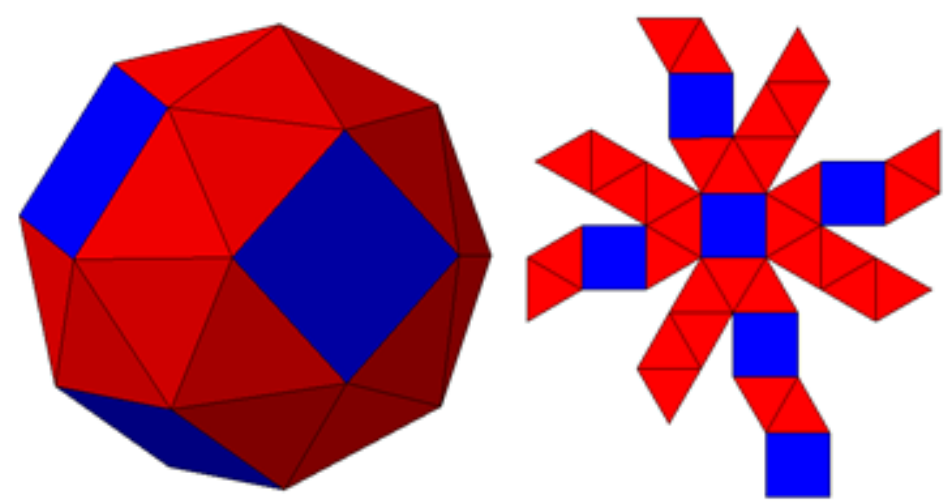

Figura 21 - Cubo achatado e sua planificação. Fonte: da autora

e. Dois quadrados e um triângulo

Tem-se um prisma triangular com um total de duas faces triangulares, três faces quadradas, nove arestas e seis vértices. 

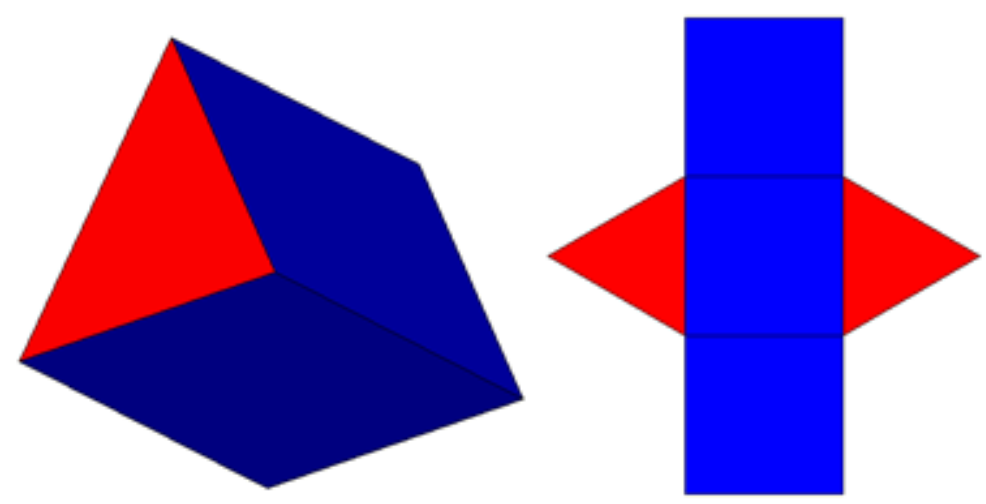

Figura 22 - Prisma de base triangular e sua planificação. Fonte: da autora

f. Dois quadrados e dois triângulos;

Neste caso existem duas possibilidades de disposição dos polígonos:
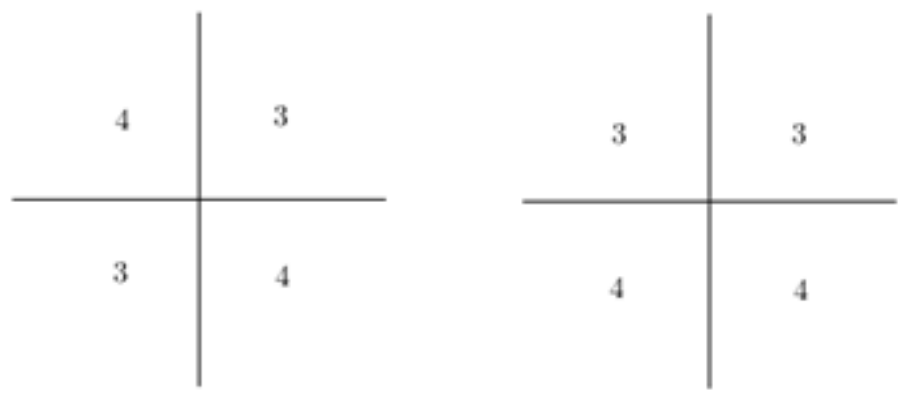

Figura 23 - Vértice com dois triângulos e dois quadrados, dispostos em $(3,4,3,4)$ e $(3,3,4,4)$ respectivamente, no sentido anti-horário.

Fonte: da autora

O segundo caso, $(3,4,3,4)$ contagem no sentido anti-horário, não é possível, sendo verificado pelo lema 2(ii).

Com a formação do primeiro caso $(3,4,3,4)$, temos o cuboctaedro. 

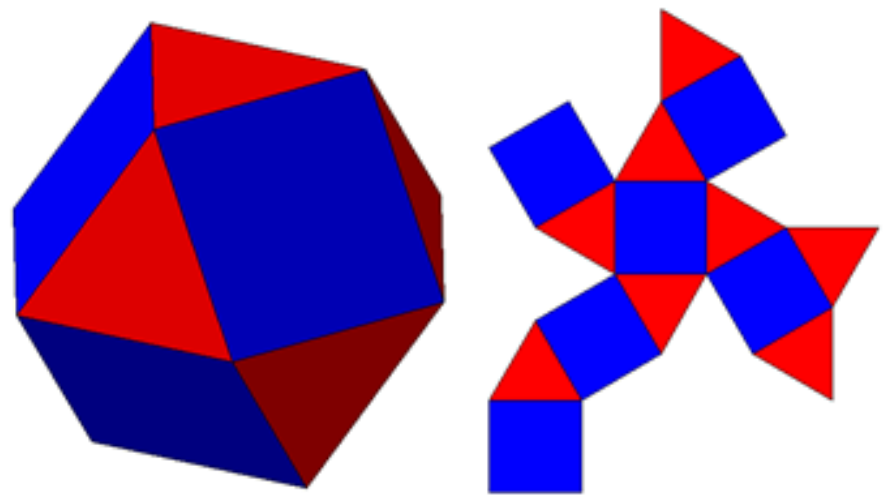

Figura 24 - Cuboctaedro e sua planificação.

Fonte: da autora

g. Três quadrados e um triângulo

Só existe uma disposição possível com esses polígonos que forma o rombicuboctaedro.
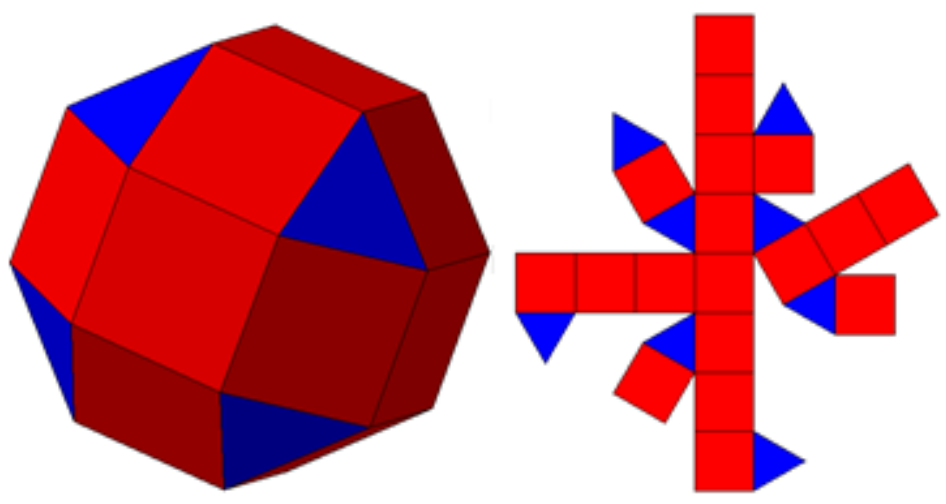

Figura 25 - Rombicuboctaedro e sua planificação. Fonte: da autora

As demais combinações com quadrados e triângulos não foram consideradas, pois a soma dos ângulos é maior que $360^{\circ}$.

\section{2) Ângulos sólidos formados por triângulos e pentágonos:}

a. Um pentágono e dois triângulos

Impossível, de acordo com o lema 2(i).

b. Um pentágono e três triângulos

Tem-se um antiprisma pentagonal com um total de duas faces pentagonais, dez faces triangulares, vinte arestas e dez vértices. 

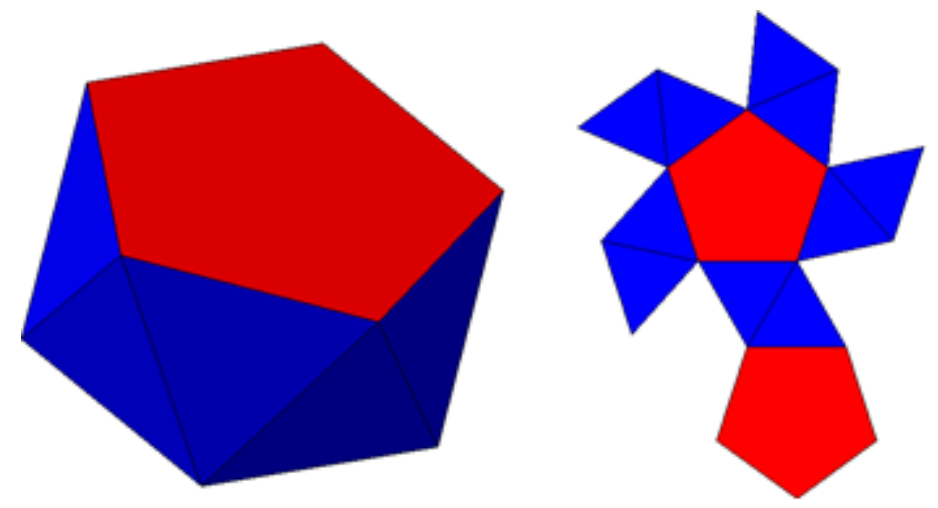

Figura 26 - Antiprisma de base pentagonal e sua planificação. Fonte: da autora

c. Um pentágono e quatro triângulos

Tem-se o snub icosidodecaedro.
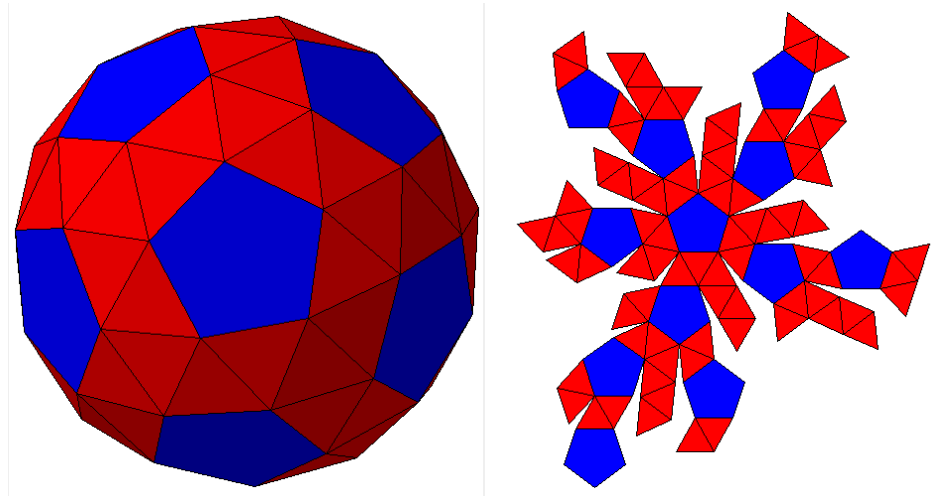

Figura 27 - Snub icosidodecaedro e sua planificação.

Fonte: da autora

d. Dois pentágonos e um triângulo

Verifica-se pelo lema 2(i), que não é possível. Basta considerar $a=5$, que é impar, e $b=5 \neq c=3$.

e. Dois pentágonos e dois triângulos

Neste caso existem duas possibilidades de disposição dos polígonos, como apresentados a seguir. 

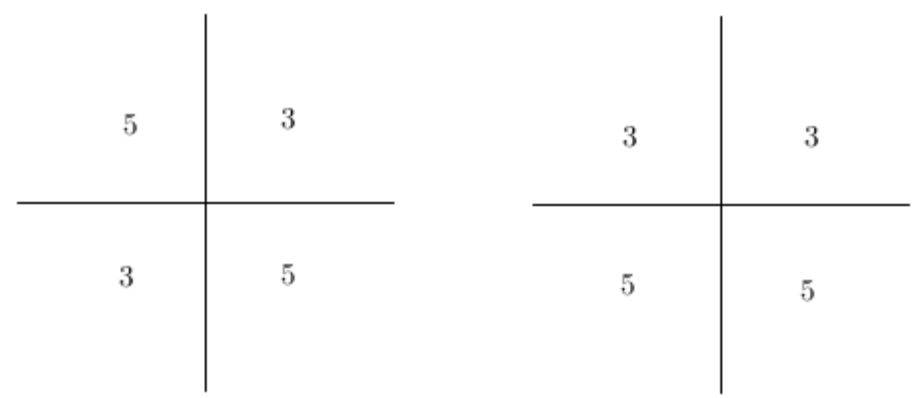

Figura 28 - Vértice com dois triângulos e dois pentágonos, dispostos em $(3,5,3,5)$ e $(3,3,5,5)$ respectivamente, no sentido anti-horário.

Fonte: da autora

O segundo caso $(3,3,5,5)$ não é possível de acordo com o lema 2(ii). Já o caso em que os polígonos estão dispostos da forma $(3,5,3,5)$, tem-se o icosidodecaedro.
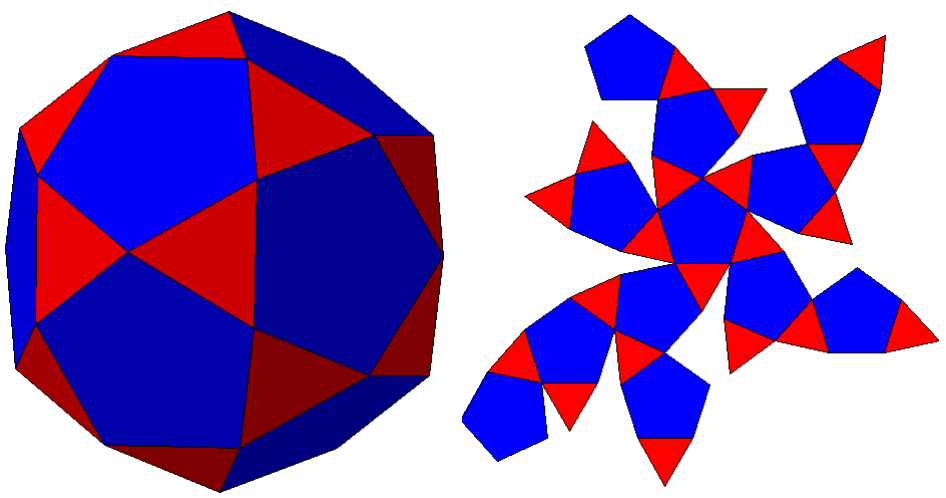

Figura 29 - Icosidodecaedro e sua planificação.

Fonte: da autora

\section{3) Ângulos sólidos formados por triângulos e hexágonos:}

a. Um hexágono e dois triângulos

Verifica-se pelo lema 2(i) que não é possível essa formação.

b. Um hexágono e três triângulos

Tem-se um antiprisma hexagonal com um total de duas faces hexagonais, doze faces triangulares, doze vértices e vinte e quatro arestas. 

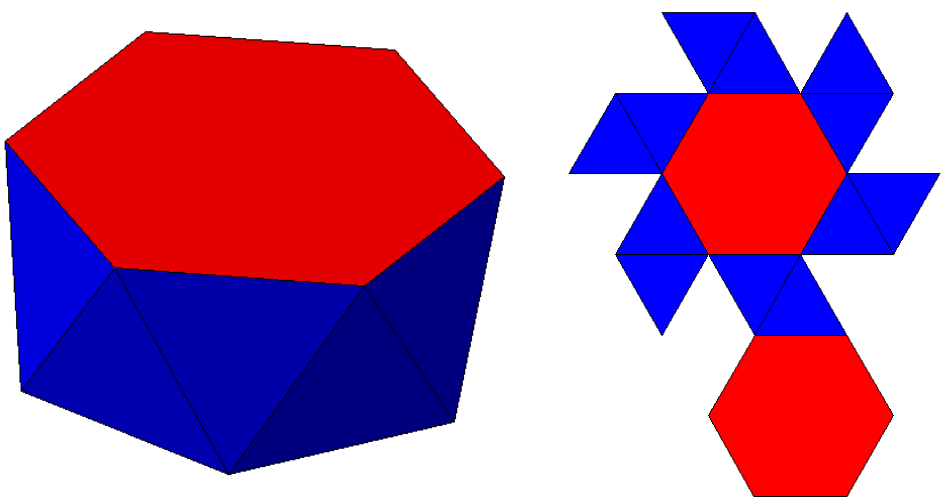

Figura 30 - Antiprisma de base hexagonal e sua planificação. Fonte: da autora

c. Dois hexágonos e um triângulo

Com essa disposição de polígonos tem-se o Tetraedro truncado.
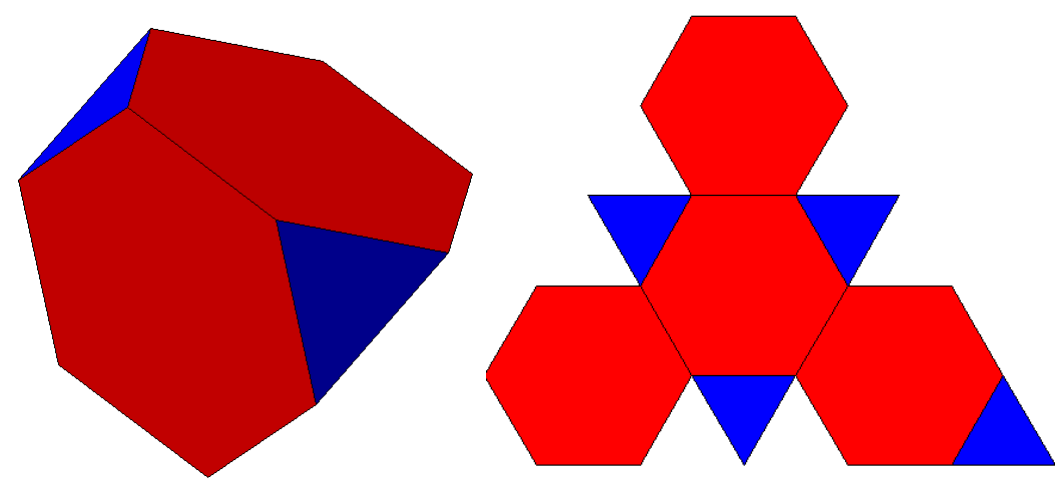

Figura 31 - Tetraedro truncado e sua planificação.

Fonte: da autora

d. A soma dos ângulos de três hexágonos é igual a $360^{\circ}$, sendo assim não forma um ângulo sólido.

4) Vejamos, agora, as possibilidades de ângulos sólidos formados por triângulos e polígonos de $\boldsymbol{n}$ lados, $\operatorname{com} \boldsymbol{n} \geq 7$.

a. Dois triângulos e um polígono de $n$ lados, $\operatorname{com} n \geq 7$, nunca formam um ângulo sólido, pois é o caso do lema $2(i)$.

b. Três triângulos e um polígono de $n$ lados, com $n \geq 7$, formam um antiprisma.

Os ângulos internos $(\alpha)$ de um polígono de $n$ lados, é sempre menor que $180^{\circ}$. Sendo assim, para qualquer polígono com $n$ lados, $n \geq 7$ tem-se a soma menor que $360^{\circ}$.

$$
3 \times\left(60^{\circ}\right)+\alpha<360^{\circ}
$$

Neste caso temos uma família infinita de antiprismas. 
c. Quatro triângulos e um polígono de $n$ lados, com $n \geq 7$ não formam um ângulo sólido, pois a soma dos ângulos dos polígonos em torno de um vértice é maior que $360^{\circ}$.

Para $n=7$, temos:

$$
4 \times\left(60^{\circ}\right)+128,57^{\circ}>360^{\circ}
$$

d. Dois polígonos de $n$ lados, com $n \geq 7$ e um triângulo.

- $\quad$ Se $n$ é impar, temos um caso impossível verificado pelo lema 2(i).

- $\quad$ Se $n$ é par, temos:

- Para $n=8$ e sendo $\alpha$ os ângulos internos do octógono.

Temos $\alpha=135^{\circ} \mathrm{e}$

$$
60^{\circ}+2 \times 135^{\circ}=330^{\circ}
$$

Formando assim um cubo truncado
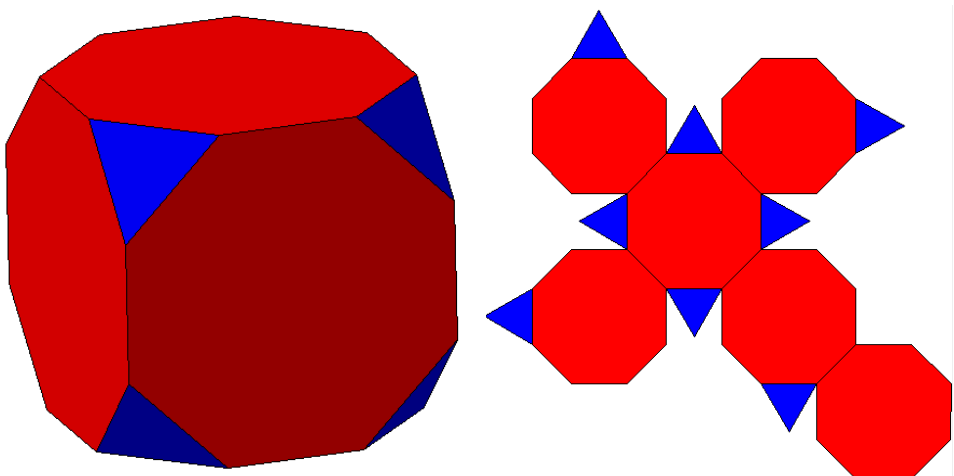

Figura 32 - Cubo truncado e sua planificação.

Fonte: da autora

- Para $n=10$ e sendo $\alpha$ os ângulos internos do decágono.

Temos $\alpha=144^{\circ} \mathrm{e}$

$$
60^{\circ}+2 \times 144^{\circ}=348^{\circ}
$$

Formando assim, um dodecaedro truncado. 

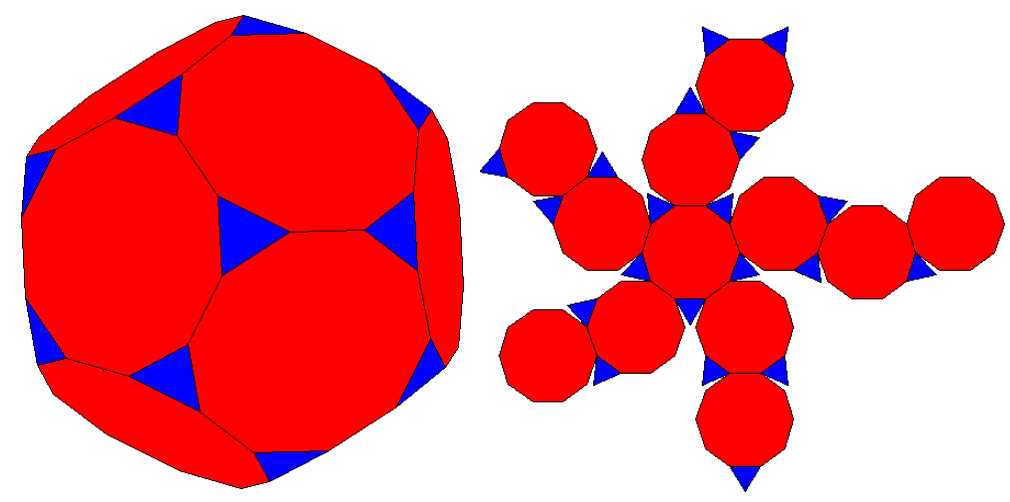

Figura 33 - Dodecaedro truncado e sua planificação.

Fonte: da autora

- Se $n=12$ e sendo $\alpha$ os ângulos internos do dodecágono.

Temos $\alpha=150^{\circ} \mathrm{e}$

$$
60^{\circ}+2 \times 150^{\circ}=360^{\circ}
$$

Para $n \geq 12$, temos a soma dos ângulos internos, maior ou igual a $360^{\circ}$, sendo assim, impossível de se formar um ângulo sólido.

5) Continuando a analisar a formação de ângulos sólidos compostos por dois tipos de polígonos, vejamos as possibilidades com quadrados e polígonos de $\boldsymbol{n}$ lados, $\operatorname{com} \boldsymbol{n} \geq \mathbf{5}$.

a. Um quadrado e dois polígonos de $n$ lados

- Se $n$ é impar, não é possível formar ângulos sólidos com essa disposição de polígonos de acordo com o lema 2(i).

- $\quad$ Sendo $n$ par, temos:

- Para $n=6$ e sendo $\alpha$ os ângulos internos do hexágono.

Temos $\alpha=120^{\circ} \mathrm{e}$

$$
90^{\circ}+2 \times 120^{\circ}=330^{\circ}
$$

Formando assim um Octaedro truncado. 


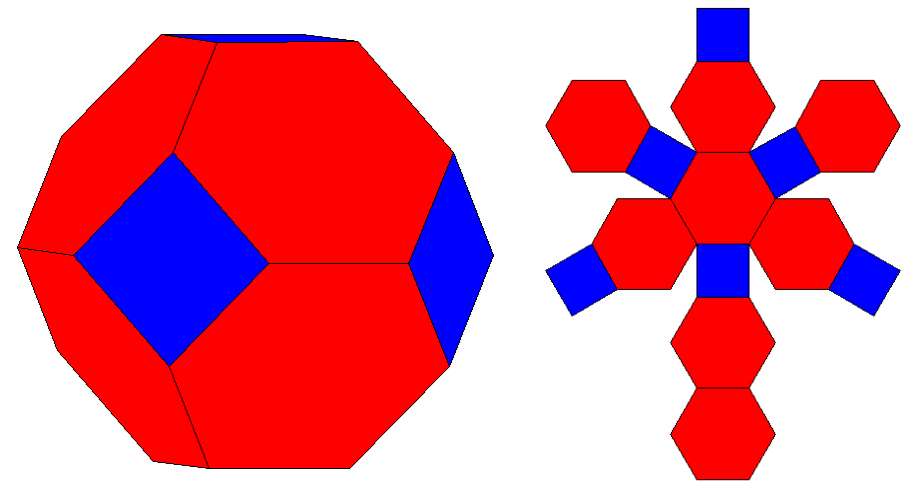

Figura 34 - Octaedro truncado e sua planificação. Fonte: da autora

○ Para $n=8$ e sendo $\alpha$ os ângulos internos do octógono. Temos $\alpha=135^{\circ} \mathrm{e}$

$$
90^{\circ}+2 \times 135^{\circ}=360^{\circ}
$$

Para $n \geq 8$, temos a soma dos ângulos internos, maior ou igual a $360^{\circ}$, sendo assim, impossível de se formar um ângulo sólido.

b. Dois quadrados e um polígono de $n$ lados

Os ângulos internos $(\alpha)$ de um polígono de $n$ lados, é sempre menor que $180^{\circ}$. Sendo assim, para qualquer polígono com $n$ lados, $n \geq 5$ temos a soma menor que $360^{\circ}$.

$$
2 \times\left(90^{\circ}\right)+\alpha<360^{\circ}
$$

Neste caso temos uma família infinita de prismas.

c. Dois quadrados e dois polígono de $n$ lados, com $n \geq 5$

- Para $n=5$ e sendo $\alpha$ os ângulos internos do pentágono. Temos $\alpha=108^{\circ} \mathrm{e}$

$$
2 \times 90^{\circ}+2 \times 108^{\circ}=396^{\circ}
$$

Logo para $n \geq 5$ não é possível formar um ângulo sólido. Daí também podemos concluir que não é possível a formação de ângulos sólidos compostos por três quadrados e um ou mais polígonos de $n$ lados, com $n \geq 5$.

6) Vejamos agora as possibilidades de ângulos sólidos formados por pentágonos e polígonos de $n$ lados, $\operatorname{com} n \geq 6$.

a. Um pentágono e dois polígonos de $n$ lados.

- $\quad$ Se $n$ é ímpar não é possível de acordo com o lema 2(i).

- Para $n=6$ e sendo $\alpha$ os ângulos internos do hexágono. Temos $\alpha=120^{\circ}$ e $108^{\circ}+2 \times 120^{\circ}=348^{\circ}$. 
Formando assim um icosaedro truncado
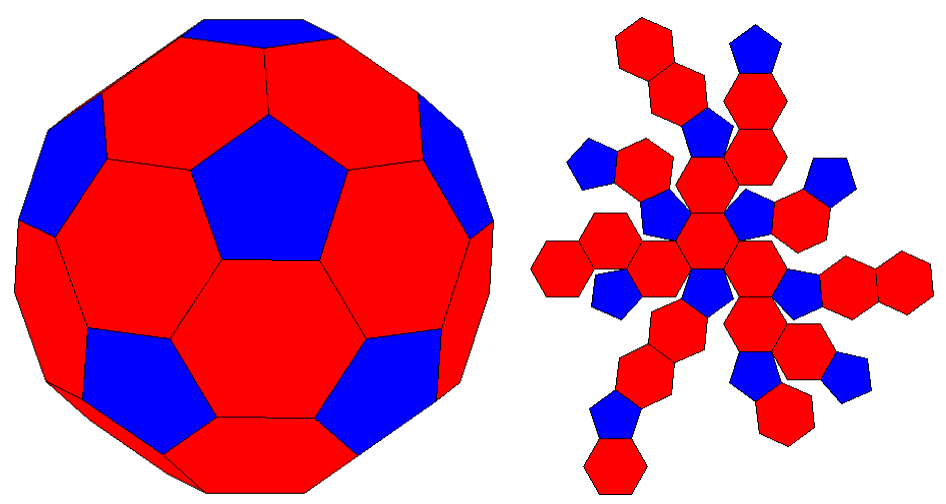

Figura 35 - Icosaedro truncado e sua planificação. Fonte: da autora

- Para $n=8$ e sendo $\alpha$ os ângulos internos do octógono. Temos $\alpha=$ $135^{\circ} \mathrm{e}$

$$
108^{\circ}+2 \times 135^{\circ}=378^{\circ}
$$

Logo para $n \geq 8$ não é possível formar um ângulo sólido.

b. Dois pentágonos e um polígono de $n$ lados

Para qualquer valor de $n$ é impossível a formação de um ângulo sólido de acordo com o lema $2(i)$.

c. Dois pentágonos e dois polígonos de $n$ lados, $\operatorname{com} n \geq 6$

Para $n=6$ e sendo $\alpha$ os ângulos internos do hexágono. Temos $\alpha=120^{\circ} \mathrm{e}$

$$
2 \times 120^{\circ}+2 \times 108^{\circ}=456^{\circ}
$$

Logo, não é possível formar um ângulo sólido composto por dois pentágonos e dois polígonos de $n$ lados para qualquer valor de $n$, com $n \geq 6$.

d. Três pentágonos e um polígono de $n$ lados, $\operatorname{com} n \geq 6$

Para $n=6$ e sendo $\alpha$ os ângulos internos deste polígono. Temos $\alpha=120^{\circ}$ e

$$
3 \times 108^{\circ}+120^{\circ}=444^{\circ}
$$

Logo, não é possível formar um ângulo sólido composto por três pentágonos e um ou mais polígonos de $n$ lados para qualquer valor de $n$.

Finalizada todas as possibilidades de ângulos sólidos compostos por dois tipos de polígonos, vejamos a análise para formação com três tipos de polígonos.

7) Ângulos sólidos formados por triângulos, quadrados e polígonos de $n$ lados, para $n \geq 5$

a. Um triângulo, um quadrado e um polígono de $\mathrm{n}$ lados, para $\mathrm{n} \geq 5$ 
Impossível, de acordo com o lema 2(i), para qualquer valor de $n$.

b. Um triângulo, um quadrado e dois ou mais polígonos de $n$ lados

Neste caso, a soma dos ângulos internos será sempre maior que $360^{\circ}$, não sendo possível a formação de um ângulo sólido.
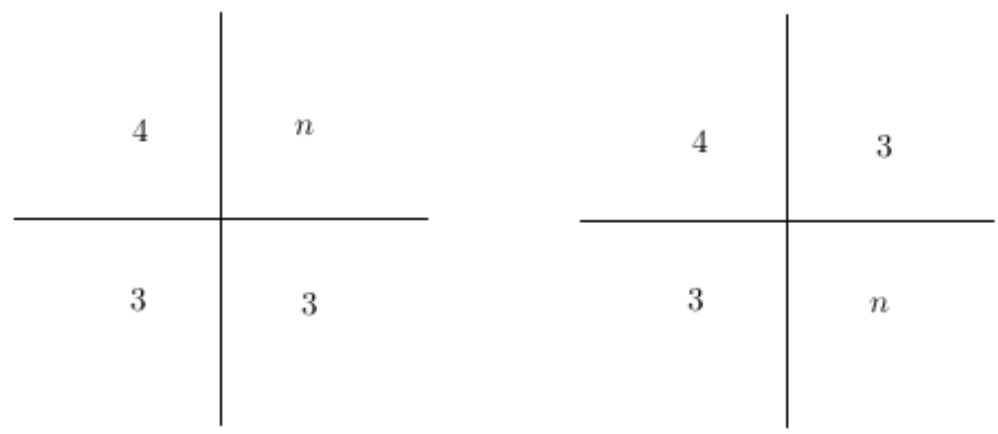

Figura 36 - Dois triângulos, um quadrado e um polígono de $\boldsymbol{n}$ lados. Fonte: da autora

Neste caso, existem duas possibilidades de disposição dos polígonos, $(n, 4,3,3)$ e $(3,4,3, n)$, ambos impossíveis de acordo com o lema 2(ii) para qualquer valor de $n$.

c) Um triângulo, dois quadrados e um polígono de $n$ lados.

- $\quad$ Para $n=5$, temos duas possibilidades de disposição dos polígonos.

○ $(3,4,4,5)$, que é um caso impossível de acordo com o lema (2ii).

○ $(3,4,5,4)$, onde temos $60^{\circ}+2 \times 90^{\circ}+108^{\circ}=348^{\circ}$

formando assim um rombicosidodecaedro.
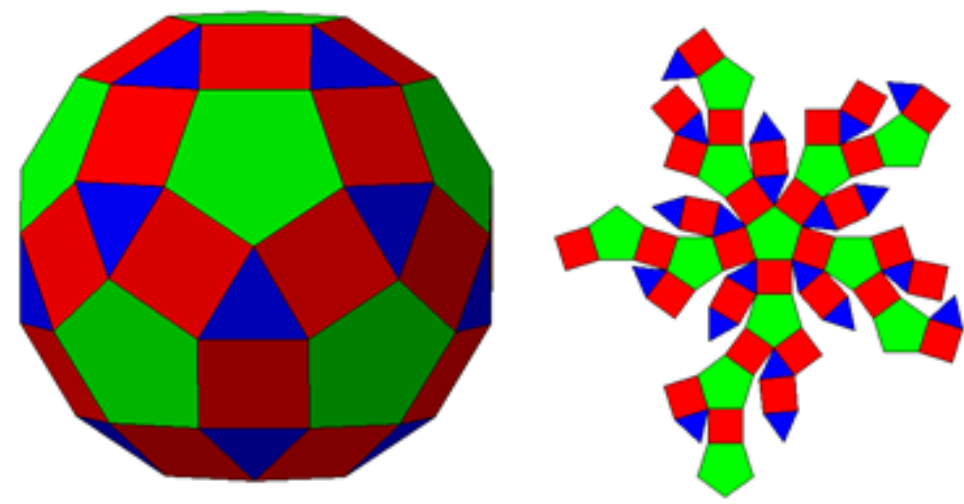

Figura 37 - Rombicosidodecaedro e sua planificação.

Fonte: da autora 
- Para $n=6$ e sendo $\alpha$ os ângulos internos do hexágono, temos duas possibilidades de disposição dos polígonos: $(3,4,4,6)$ e $(3,4,6,4)$, ambos $\operatorname{com} \alpha=120^{\circ} \mathrm{e}$

$$
60^{\circ}+2 \times 90^{\circ}+120^{\circ}=360^{\circ}
$$

Sendo assim, não é possível formar um ângulo sólido.

8) Ângulos sólidos formados por três tipos de faces, onde nenhuma delas é um polígono de 3 lados.

a. Suponhamos, inicialmente, um ângulo sólido formado por quatro polígonos. A menor combinação possível será com dois quadrados, um pentágono e um hexágono. Onde a soma dos ângulos internos desses polígonos é maior que $360^{\circ}$, sendo assim contraditória a formação desse ângulo.

$$
2 \times 90^{\circ}+108^{\circ}+120^{\circ}=408^{\circ}
$$

Vejamos, então, os ângulos formados por três polígonos.

b. O lema 2(i) imediatamente exclui as possibilidades em que ao menos um dos polígonos possua um número ímpar de lados.

c. A primeira menor combinação de três polígonos de número par de lados é com um quadrado, um hexágono e um octógono. Que forma o cuboctaedro truncado ou grande rombicuboctaedro.

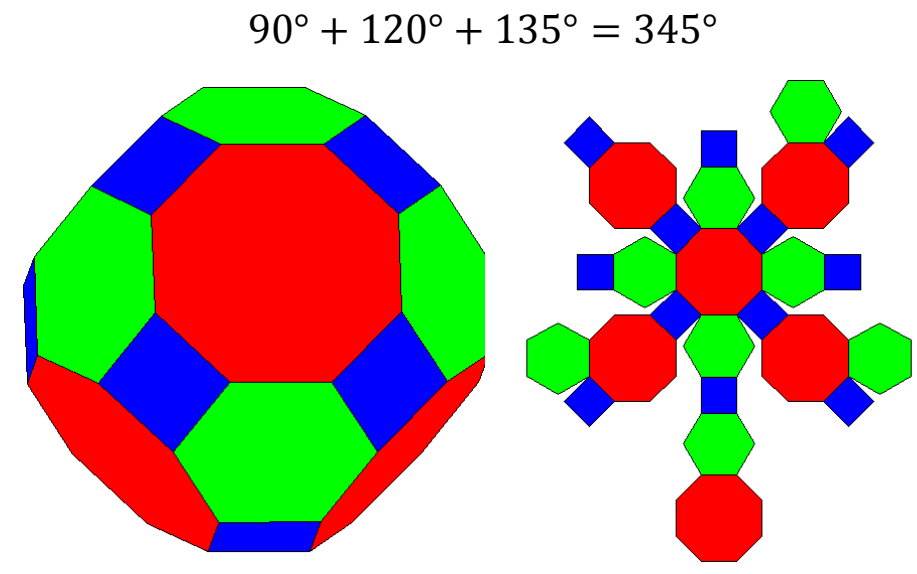

Figura 38 - Cuboctaedro truncado ou grande rombicuboctaedro e Fonte: da autora sua planificação.

d. A segunda menor combinação de três polígonos com número par de lados é com um quadrado, um hexágono e um decágono. Que forma o icosidodecaedro truncado ou rombicosidodecaedro. 


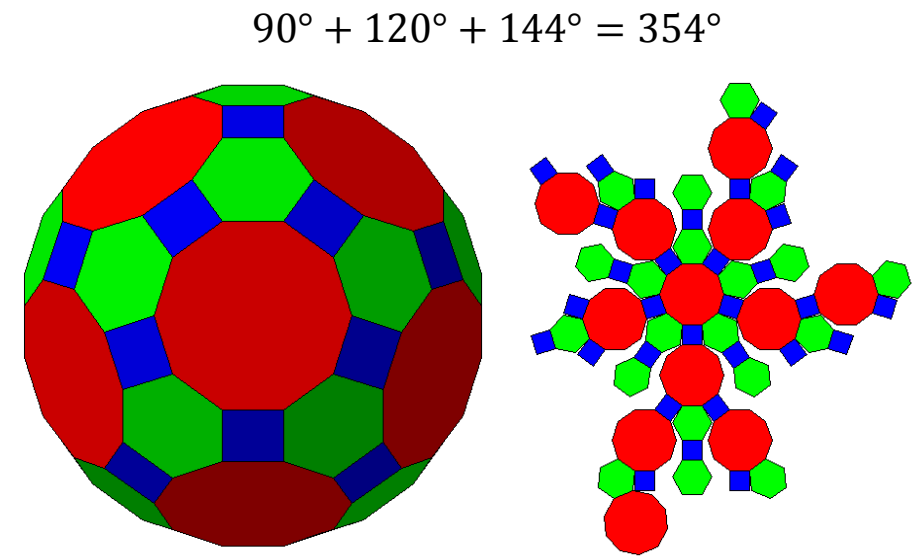

Figura 39 - Icosidodecaedro truncado ou rombicosidodecaedro e Fonte: da autora sua planificação.

e. A terceira menor combinação de três polígonos com número par de lados é com um quadrado, um octógono e um dodecágono. No entanto a soma de seus ângulos internos ultrapassa $360^{\circ}$.

$$
90^{\circ}+135^{\circ}+150^{\circ}=375^{\circ}
$$

Qualquer outra combinação de três polígonos com número par de lados terá a soma de seus ângulos internos maior que $360^{\circ}$, não sendo possível formar um ângulo sólido.

Vistas todas as possibilidades de formar ângulos sólidos, compostos por polígonos regulares de mais de um tipo, e todas as disposições possíveis desses polígonos em torno do vértice, obtemos os poliedros semirregulares. Ao separar a família infinita dos prismas e dos antiprismas, restam treze poliedros que são conhecidos como os Poliedros de Arquimedes.

No entanto, Miller, ao estudar os treze poliedros de Arquimedes, descobre a suposta existência de mais um poliedro.

Também conhecido como "O erro de Miller", o pseudorrombicuboctaedro possui o mesmo número de faces, arestas e vértices que o rombicuboctaedro; no entanto, não tem a mesma simetria em sua estrutura.

"The true Archimedean solids, like the Platonic solids, have an aesthetic quality which Miller's solid does not possess. This attractiveness comes from their high degree of symmetry" (GRUNBAUM, 2009).

A seguir são apresentados dois critérios para definição de poliedros semirregulares, que Grunbaum traz em seu artigo: 
Critério local: Todas as faces são polígonos regulares e o arranjo cíclico das faces em torno de cada vértice é a mesma.

Critério global: Todas as faces são polígonos regulares e todos os vértices formam em órbita sob simetrias isométricas do poliedro.

Daí conclui-se que o critério global exclui o pseudorrombicuboctaedro, sendo essa definição a mais adequada para os treze poliedros conhecidos como Arquimedianos.

Soler (2007, p.135) também sugere uma definição para excluir o décimo quarto poliedro: "são poliedros que possuem faces regulares de mais de uma classe, enquanto que todos os vértices se transformam um nos outros por seu grupo de rotação."

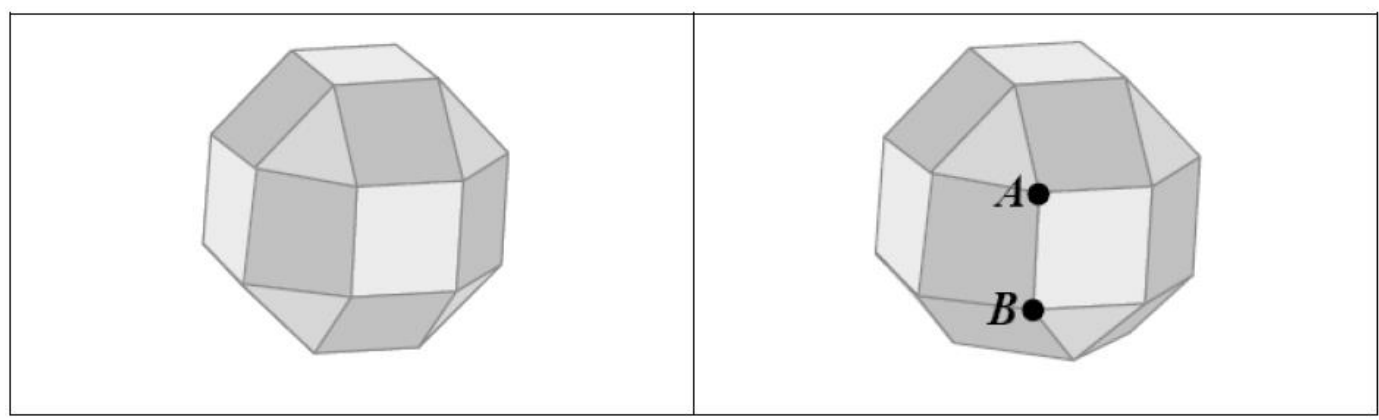

Figura 40 - Rombicuboctaedro e pseudorrombicuboctaedro. Fonte: Veloso (1998, p. 241)

Ao observar os dois sólidos em questão, pode-se constatar uma rotação de $45^{\circ}$ em parte do pseudorrombicuboctaedro. 


\section{OS POLIEDROS ARQUIMEDIANOS A PARTIR DE TRUNCATURAS}

Além das características que definem os treze poliedros de Arquimedes, alguns deles também podem ser obtidos através de truncaturas nos vértices dos poliedros de Platão. Essas truncaturas ou sucessão de cortes são feitos por planos perpendiculares ao eixo de simetria de rotação que passa pelo determinado vértice, formando uma nova face poligonal regular. Vejamos como se obtém cada um deles.

Fazendo truncaturas nos vértices do tetraedro de forma que todos os polígonos que formam as faces sejam congruentes, obtém-se o tetraedro truncado.
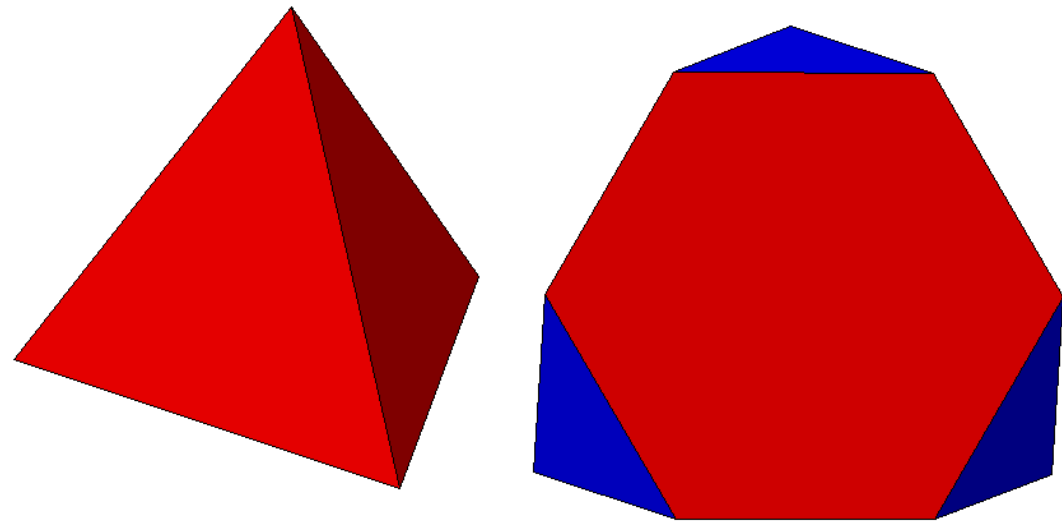

Figura 41 - Tetraedro e tetraedro truncado. Fonte: da autora

Tabela 8 - Número de faces, vértices e arestas do tetraedro e do tetraedro truncado.

\begin{tabular}{lccc}
\hline & Faces & Vértices & Arestas \\
\hline Tetraedro & 4 & 4 & 6 \\
Tetraedro truncado & $\begin{array}{l}4 \text { triângulos } \\
\text { equiláteros } \\
4 \text { hexágonos } \\
\text { regulares }\end{array}$ & 12 & 18 \\
& & & \\
\hline
\end{tabular}

Fonte: da autora

Se os cortes forem feitos passando pelo ponto médio de cada aresta, obtémse o octaedro, que é um poliedro platônico. 
2. Fazendo truncaturas nos vértices do hexaedro de forma que todos os polígonos que formam as faces sejam congruentes, obtém-se o cubo truncado. E se as truncaturas forem feitas passando pelo ponto médio de cada aresta obtém-se o cuboctaedro.
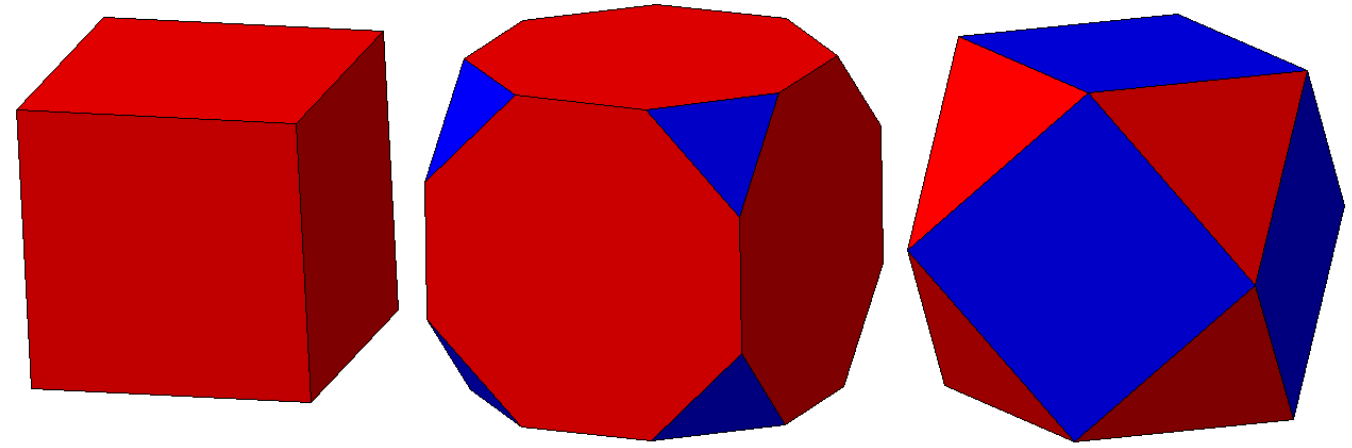

Figura 42 - Cubo, cubo truncado e cuboctaedro.

Fonte: da autora

Tabela 9 - Número de faces, vértices e arestas do cubo, cubo truncado e do cuboctaedro.

\begin{tabular}{lccc}
\hline & Faces & Vértices & Arestas \\
\hline Cubo & 6 & 8 & 12 \\
Cubo truncado & $\begin{array}{l}8 \text { triângulos } \\
\text { equiláteros } \\
6 \text { octógonos } \\
\text { regulares } \\
\text { Cuboctaedro }\end{array}$ & 24 & 36 \\
\hline triângulos & & \\
\hline 6 quiláteros & 12 & 24 \\
\hline
\end{tabular}

Fonte: da autora

3. Fazendo truncaturas nos vértices do octaedro de forma que todos os polígonos que formam as faces sejam congruentes, obtém-se o octaedro truncado. E se as truncaturas forem feitas passando pelo ponto médio de cada aresta obtém-se o cuboctaedro. 

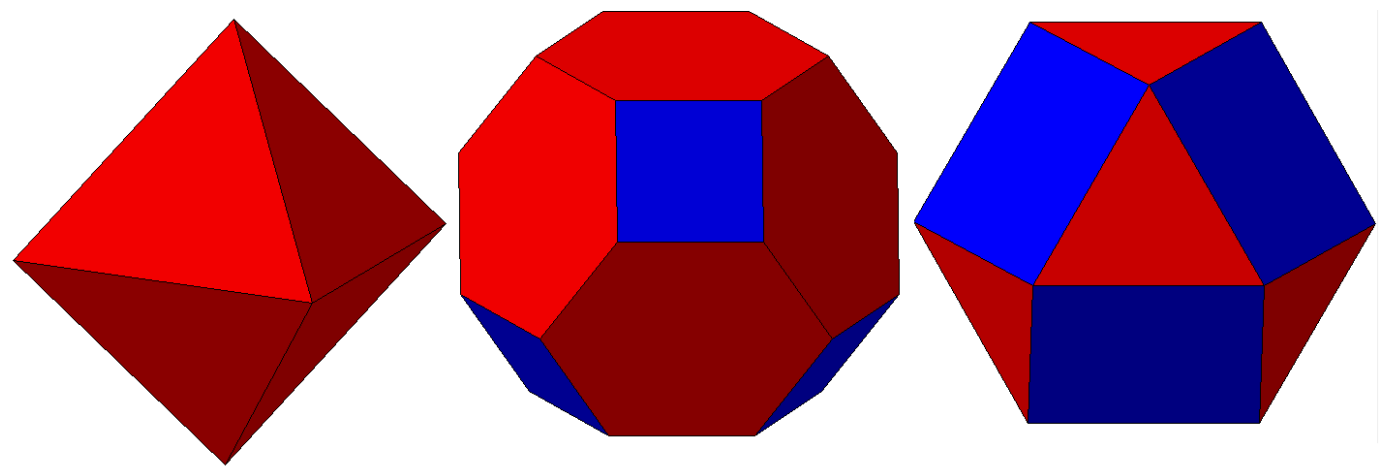

Figura 43 - Octaedro, octaedro truncado e cuboctaedro.

Fonte: da autora

Tabela 10 - Número de faces, vértices e arestas do octaedro, e do octaedro truncado.

\begin{tabular}{lccc}
\hline & Faces & Vértices & Arestas \\
\hline Octaedro & 8 & 6 & 12 \\
Octaedro truncado & $\begin{array}{l}6 \text { quadrados } \\
8 \text { hexágonos } \\
\text { regulares }\end{array}$ & 24 & 36 \\
\hline
\end{tabular}

Fonte: da autora

4. Fazendo truncaturas nos vértices do dodecaedro de forma que todos os polígonos que formam as faces sejam congruentes, obtém-se o dodecaedro truncado. E se as truncaturas forem feitas passando pelo ponto médio de cada aresta obtém-se o icosidodecaedro.

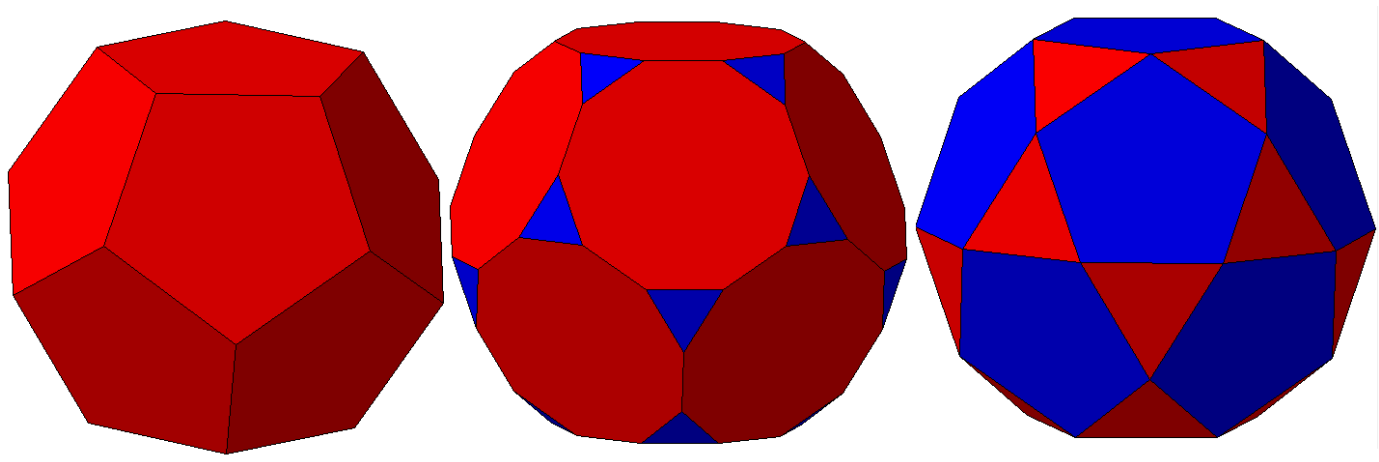

Figura 44 - Dodecaedro, dodecaedro truncado e icosidodecaedro. Fonte: da autora 
Tabela 11 - Número de faces, vértices e arestas do dodecaedro, dodecaedro truncado e do icosidodecaedro.

\begin{tabular}{lccc}
\hline & Faces & Vértices & Arestas \\
\hline Dodecaedro & 12 & 20 & 30 \\
$\begin{array}{l}\text { Dodecaedro } \\
\text { truncado }\end{array}$ & $\begin{array}{c}\text { equiláteros } \\
12 \text { decágonos } \\
\text { regulares }\end{array}$ & 60 & 90 \\
$\begin{array}{c}20 \text { triângulos } \\
\text { equiláteros } \\
\begin{array}{c}\text { p pentágonos } \\
\text { regulares }\end{array}\end{array}$ & 30 & 60 \\
Icosidodecaedro & & \\
\hline
\end{tabular}

Fonte: da autora

5. Fazendo truncaturas nos vértices do Icosaedro de forma que todos os polígonos que formam as faces sejam congruentes, obtém-se o icosaedro truncado. E se as truncaturas forem feitas passando pelo ponto médio de cada aresta obtém-se o icosidodecaedro.
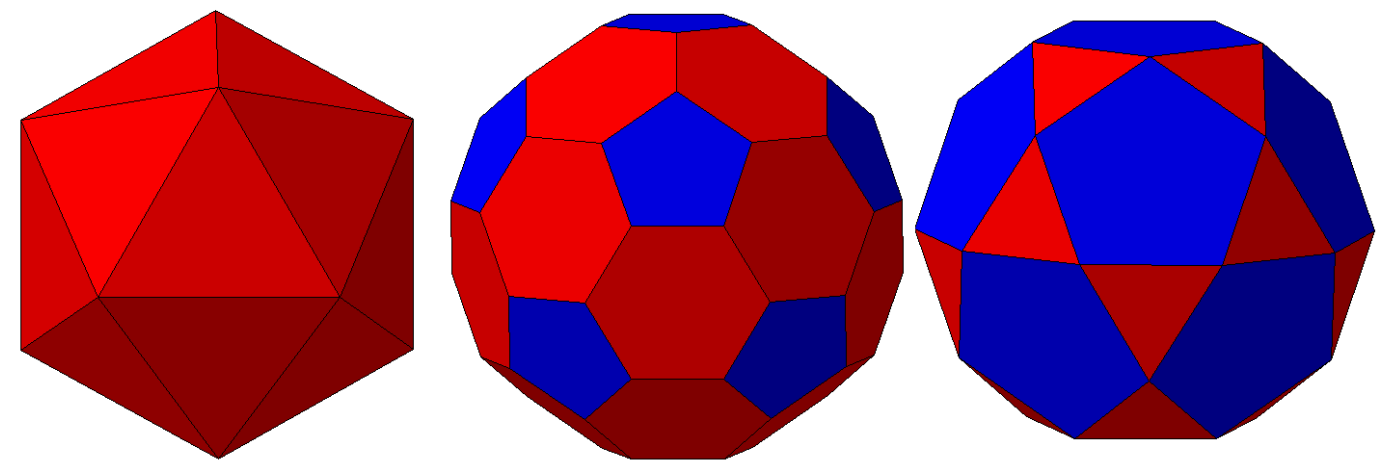

Figura 45 - Icosaedro, icosaedro truncado e icosidodecaedro.

Fonte: da autora

Tabela 12 - Número de faces, vértices e arestas do icosaedro e do icosaedro truncado.

\begin{tabular}{lccc}
\hline & Faces & Vértices & Arestas \\
\hline Icosaedro & 20 & 12 & 30 \\
Icosaedro truncado & $\begin{array}{c}12 \text { pentágonos } \\
\text { regulares } \\
20 \text { hexágonos } \\
\text { regulares }\end{array}$ & 60 & 90 \\
\hline
\end{tabular}

Fonte: da autora 
Os sete poliedros Arquimedianos apresentados ate aqui são obtidos direto de truncaturas dos poliedros Platônicos e são nomeados de acordo com o poliedro Platônico "de origem". No caso do cuboctaedro e icosidodecaedro que podem ser obtidos a partir do cubo ou octaedro e do dodecaedro ou icosaedro respectivamente, também têm a nomenclatura justificada.

Ao truncar os vértices do cuboctaedro não obtemos uma face quadrada, pois em um mesmo vértice concorrem dois triângulos e dois quadrados, e ao observar os ângulos internos dos mesmos, verificamos a formação de uma face retangular. Dessa forma, é necessário transformar esses retângulos em quadrados para formar o grande rombicuboctaedro ou cuboctaedro truncado. Caso essa truncatura seja feita passando pelo ponto médio das faces do cuboctaedro, serão obtidas também faces retangulares que, se transformadas em quadrados, formarão o rombicuboctaedro.
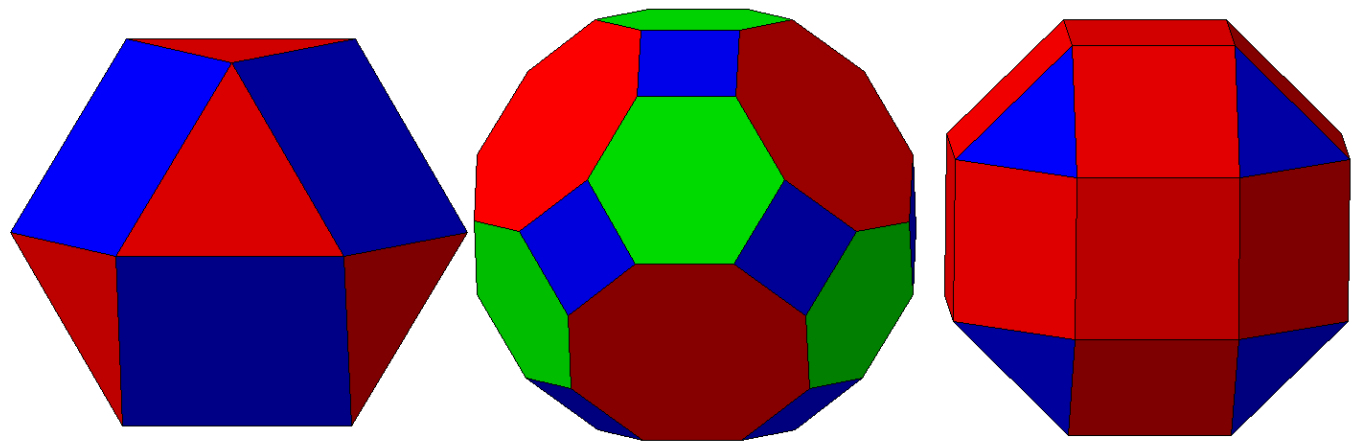

Figura 46 - Cuboctaedro, cuboctaedro truncado e rombicuboctaedro. Fonte: da autora

Tabela 13 - Número de faces, vértices e arestas do cuboctaedro truncado e do rombicuboctaedro.

\begin{tabular}{lccc} 
& Faces & Vértices & Arestas \\
\hline Cuboctaedro truncado & 12 quadrados & & \\
& 8 hexágonos & 48 & 72 \\
& 6 octógonos & & \\
& 8 triângulos & & 42 \\
Rombicuboctaedro & equiláteros & 24 & \\
& 18 quadrados & & \\
\hline
\end{tabular}

Fonte: da autora

Ao truncar os vértices do Icosidodecaedro, igualmente terá que ser feita a transformação dos retângulos resultantes em quadrados, de forma a se obter o 
grande rombicosidodecaedro ou icosidodecaedro truncado. E se as truncaturas forem feiras passando pelo ponto médio das arestas das faces e também realizando a transformação necessária dos retângulos resultantes em quadrados, obteremos o rombicosidodecaedro.
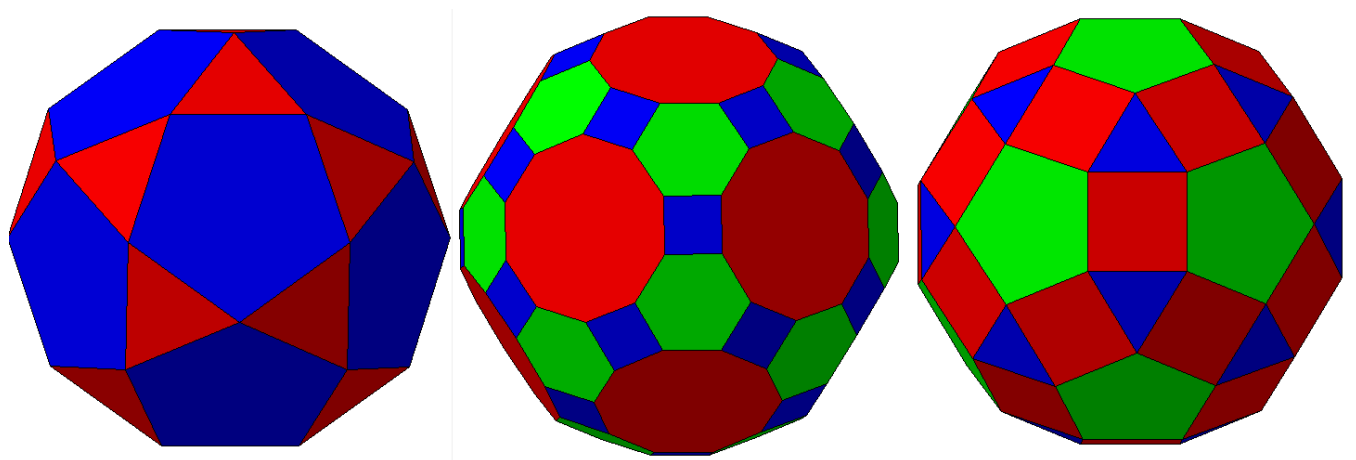

Figura 47 - Icosidodecaedro, icosidodecaedro truncado e rombicosidodecaedro. Fonte: da autora

Tabela 14 - Número de faces, vértices e arestas do icosidodecaedro truncado e do rombicosidodecaedro.

\begin{tabular}{lccc}
\hline & Faces & Vértices & Arestas \\
\hline Icosidodecaedro truncado & 30 quadrados & & \\
& 20 hexágonos & 120 & 180 \\
& 12 decágonos & & \\
& 20 triângulos & & 120 \\
Rombicosidodecaedro & equiláteros & 60 & \\
& 30 quadrados & & \\
& 12 pentágonos \\
regulares & & \\
\hline
\end{tabular}

Fonte: da autora

A utilização do prefixo "Rombi" se dá pelo fato desses poliedros poderem ser inscritos em sólidos com faces rômbicas.

Para finalizar, vejamos os poliedros Arquimedianos achatados, que não podem ser obtidos de truncaturas sucessivas, como os anteriores. Eles são obtidos através da snubificação, uma operação sobre o poliedro que afasta as faces do mesmo, gira a um determinado ângulo e preenche os espaços vazios com outros polígonos. 

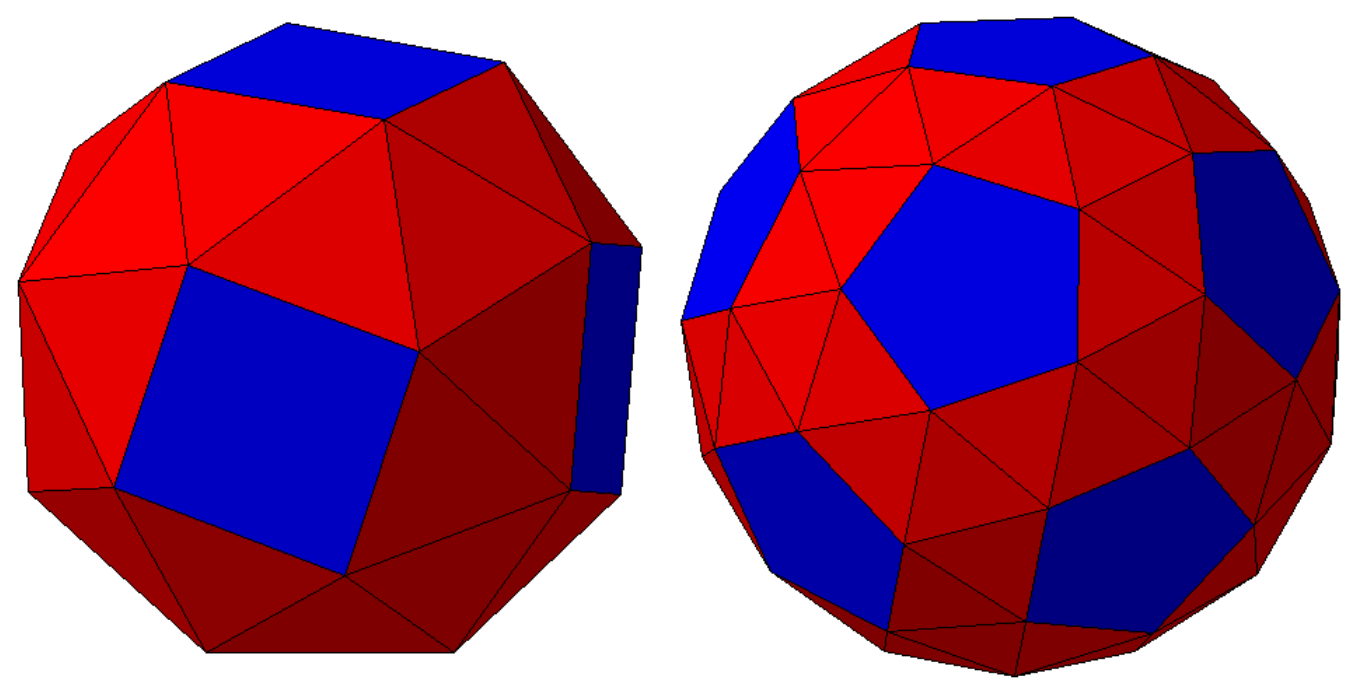

Figura 48 - Snub cuboctaedro e snub icosidodecaedro.

Fonte: da autora

O snub cuboctaedro ou cubo achatado é obtido pela snubificação do cubo, e o snub icosidodecaedro ou dodecaedro achatado pela snubificação do dodecaedro. Eles também podem ser obtidos por truncaturas especiais do octaedro e do icosaedro respectivamente.

Tabela 15 - Número de faces, vértices e arestas do snub cuboctaedro e do snub icosidodecaedro.

\begin{tabular}{lccc}
\hline & Faces & Vértices & Arestas \\
\hline Snub cuboctaedro & $\begin{array}{l}32 \text { triângulos } \\
6 \text { quadrados }\end{array}$ & 24 & 60 \\
& $\begin{array}{c}80 \text { triângulos } \\
\text { equiláteros } \\
12 \text { pentágonos } \\
\text { regulares }\end{array}$ & 60 & 150 \\
& & & \\
\hline
\end{tabular}

Fonte: da autora 


\section{O SOFTWARE POLY}

A utilização do software Poly foi de grande importância no desenvolvimento inicial do trabalho, uma das ferramentas utilizadas para visualização dos poliedros, suas respectivas planificações e o processo dessa transformação.

O programa também permite a visualização de outros poliedros além dos tratados aqui, por exemplo: os prismas e antiprismas, poliedros de Johnson, Deltaedros, poliedros de Catalão, Dipiramides, Deltoedros, e Esferas e Domos Geodésicos. Além de variadas formas de visualização desses poliedros, como apenas os vértices, apenas as arestas dos poliedros ou a projeção das arestas no plano.

Nesse momento vale lembrar a diferença entre sólido e poliedro. A palavra sólido se refere a algo que está preenchido, que seja maciço, e como este trabalho envolve também planificação, não faz sentido falar em planificar um sólido, por isso a palavra utilizada é poliedro. Com exceção deste capítulo, uma vez que o programa em foco utiliza o termo sólido.

O software pode ser encontrado para download no site do desenvolvedor http://peda.com/ ou em http://www2.mat.ufrgs.br/edumatec/softwares/soft_geometria.php\#topo. O último link disponibiliza, além do Poly, outros softwares de geometria.

Inicialmente é disponibilizada uma cópia não registrada do programa, para demonstração e avaliação, que pode ser usada por tempo indeterminado, basta clicar em "continue" todas as vezes que o programa sugerir o registro. 


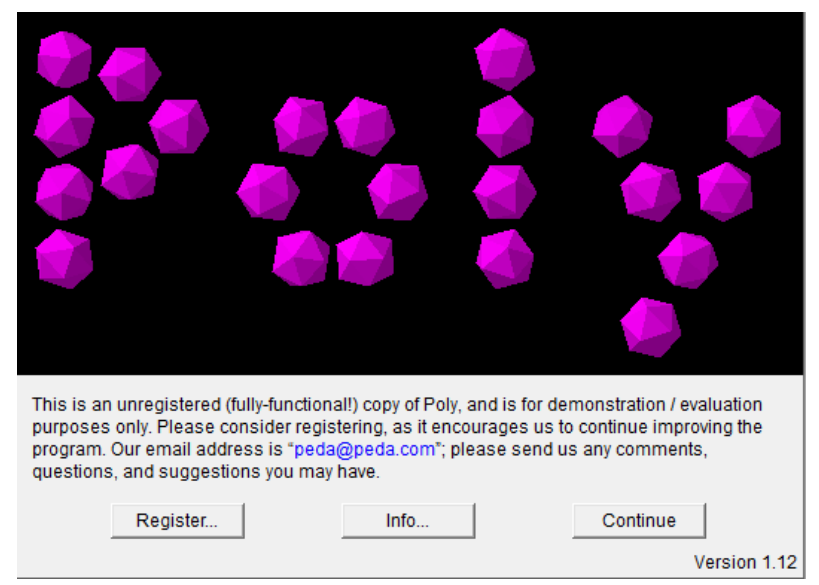

Figura 49 - Tela inicial do Poly Fonte: da autora

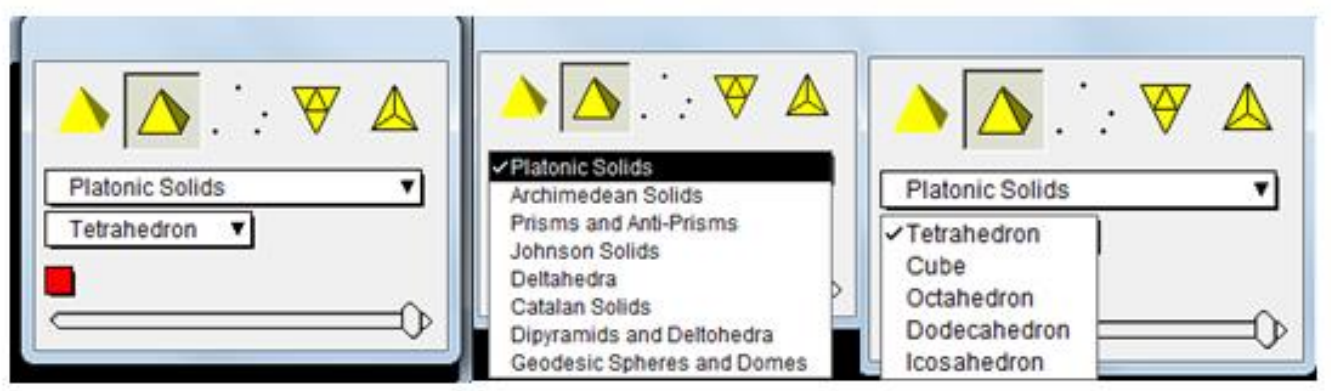

Figura 50 - Opções na barra de ferramentas.

Fonte: da autora

O botão de rolagem que fica na parte inferior da barra de ferramentas, permite abrir e fechar o poliedro, de forma a visualizar essa transformação do início ao fim, de poliedro à planificação.

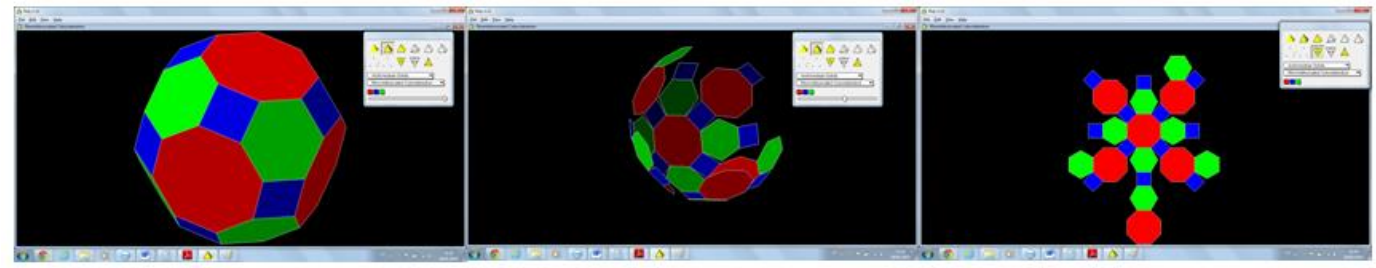

Figura 51 - Etapas da transformação da visualização do poliedro em planificação Fonte: da autora

É possível adicionar à barra de ferramentas outras opções de visualização. Indo até a aba Files-Preferences-Available View Modes, é possível selecionar as opções que desejar adicionar ou remover. 


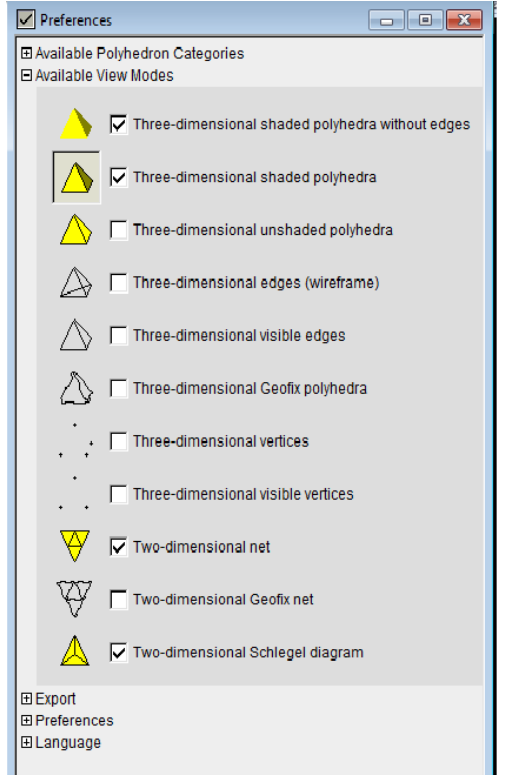

Figura 52 - Mais opções de visualização.

Fonte: da autora 


\section{O TRABALHO EM PRÁTICA}

\subsection{A escola}

O trabalho foi desenvolvido com os alunos da Escola Estadual Dôrval Ferreira da Cunha, que fica situada na Avenida Eugênio Borges, sem número, Km 6,5, Rio do Ouro, no município de São Gonçalo, RJ. A escola possui atualmente um mil, quinhentos e quarenta e cinco alunos, sendo 180 em horário integral. O prédio é composto por vinte salas de aula, todas climatizadas e distribuídas em dois prédios de dois andares cada um, um refeitório, vinte e quatro banheiros para alunos, cinco banheiro para professores, uma quadra de futebol e uma de vôlei, uma sala de vídeo, uma sala de informática, uma biblioteca, um laboratório, uma sala de matemática, uma sala de educação física, uma sala de artes e uma sala de recursos, totalizando 7200 metros quadrados e aproximadamente 2800 metros quadrados de área livre.

A sala Sesi, chamada de "Sala da Matemática", é uma sala doada pela FIRJAN (Federação das Indústrias do Estado do Rio de Janeiro), em parceria com a própria escola. A sala é equipada com quarenta notebooks, um quadro interativo, internet de alta velocidade, além do material de apoio. No estado do Rio de Janeiro há apenas oito escolas que possuem esta sala e a manutenção, assim como a capacitação dos professores para utilização da sala, é uma responsabilidade da instituição parceira.

A maioria dos encontros ocorreu na Sala de Matemática, pela disponibilidade de recursos sendo, por isso, uma sala que encanta os alunos por seu conforto e tecnologia, o que já é um ponto positivo para despertar o interesse do aluno.

Por outro lado, a escola com todo seu espaço físico livre, é agradável para os alunos conversarem, jogarem bola, se divertirem de uma maneira geral. É o cenário perfeito para a socialização entre eles, uma vez que o bairro onde está localizada a escola é desprovido de tais espaços destinados ao lazer. Então é o "quintal" da escola que os atrai. 
Todo esse espaço livre e agradável é refém de uma difícil administração, uma vez que o número de inspetores e porteiros não é suficiente para exercer um eficaz controle a todos esses alunos em seus horários de entrada e saída. E é aí que entra a tão importante missão do professor de fazer a aula ser mais interessante ao aluno do que todo o lazer que o espera lá fora.

Com a utilização da Sala de Matemática, percebeu-se uma frequência mais efetiva às aulas e que os alunos sentiam-se mais atraídos pelos assuntos abordados.

A escola apoiou cada parte do desenvolvimento do trabalho, disponibilizando material de qualidade para confecção dos poliedros, ônibus e almoço para todos os alunos e professores no dia da oficina, que aconteceu como culminância do projeto, no SESC de São Gonçalo.

\subsection{Metodologia}

Este trabalho foi desenvolvido com as turmas 2002 e 2003, turmas do segundo ano do ensino médio, ocorrendo em três etapas, distribuídas ao longo do terceiro e quarto bimestres do ano de 2014. A primeira se deu nos encontros em sala de aula, onde foi trabalhado o conteúdo junto à construção dos sólidos. Essa etapa é a mais longa e a de maior desenvolvimento do conteúdo do trabalho.

O segundo momento consiste na apresentação dos Poliedros de Platão e dos Poliedros de Arquimedes na Mostra Cultural, que ocorreu na própria escola, no dia três de outubro de 2014. Nessa oportunidade, todos os presentes (docentes, discentes e demais funcionários) puderam visualizar, por meio do trabalho exposto pelos alunos, como se obtém cada um dos Poliedros de Arquimedes através da secção dos respectivos Poliedros de Platão. O terceiro momento foi na Primeira Feira Regional da Metropolitana II, onde cinquenta escolas expuseram seus trabalhos, sendo o da Escola Estadual Dôrval Ferreira da Cunha o único relacionado a Matemática. O stand recebeu visitas de alunos e professores de diversas escolas de São Gonçalo. Esta terceira etapa foi a de conclusão e retorno. Os alunos trabalharam diretamente com o púbico o porquê de só existirem cinco Poliedros de Platão e como se obtém os treze Poliedros de Arquimedes. Eles ensinavam aos visitantes como construir os sólidos, no decorrer da explicação, 
oferecendo material ao visitante para que este também manipulasse e não somente observasse.

\subsubsection{Primeira etapa}

No início de cada encontro desta primeira etapa, era apresentada a planificação do poliedro a ser construído. Com o auxílio do Poly, visualizávamos detalhadamente a transformação dessa planificação em seu respectivo sólido. Em poucos segundos era possível acompanhar o processo do ponto de partida até o objetivo final da construção. A utilização deste programa foi de grande importância no desenvolvimento do trabalho, pelas diversas formas de visualização.

O uso do programa foi feito de forma expositiva no quadro interativo. No entanto, ocorreu o momento de exploração do programa por parte dos alunos para que visualizassem os outros sólidos, além dos que seriam tratados ao longo do trabalho.

Quando eles estavam com as planificações impressas, já tinham em mente onde iriam chegar. No entanto, antes que se apresentasse esse processo de transformação no devido programa, era feito o questionamento sobre qual sólido se formaria a partir daquela planificação, se eles já conheciam ou sabiam o nome. Isso se fez necessário, pois o aluno possui uma bagagem de conteúdos e precisamos valorizar a contribuição dele na aula.

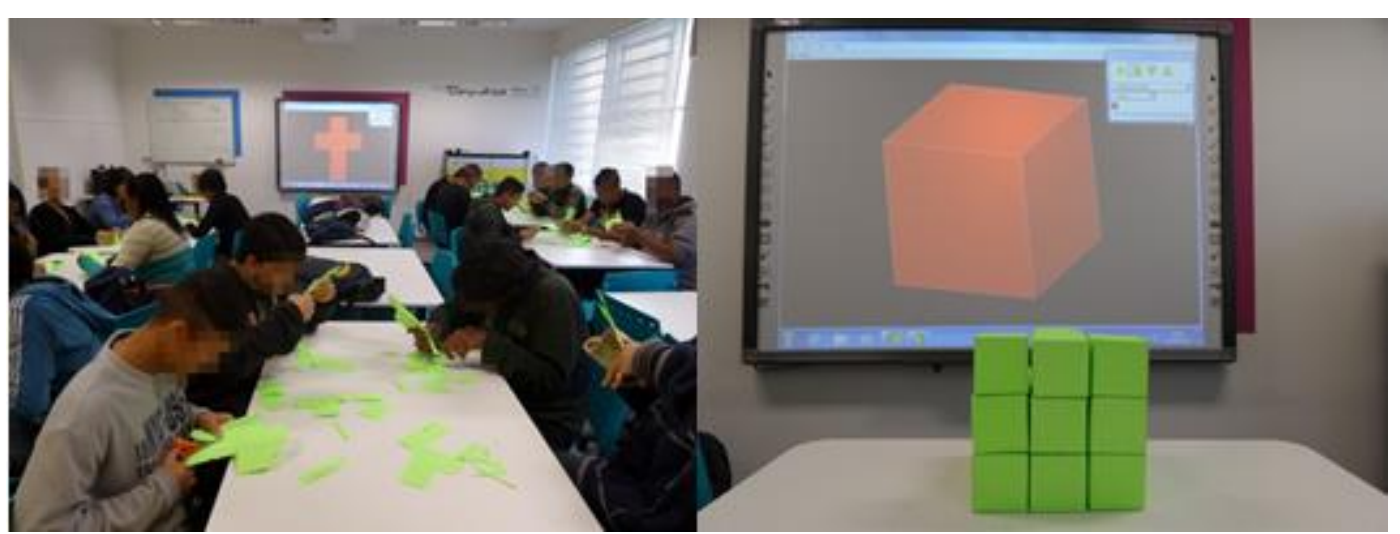

Figura 53 - Alunos produzindo o Cubo.

Fonte: da autora

Antes que iniciassem a construção do sólido, foi solicitado aos alunos que contassem quantos polígonos havia na planificação dada, para que eles 
entendessem que as faces de um poliedro são polígonos e aos poucos ficasse clara a diferença entre polígonos e poliedros. Além disso, pela facilidade, pois quando o poliedro está montado e quanto maior o número de faces que ele possui, mais difícil fica para contar. No entanto, após ele estar montado, também é interessante trabalhar essa contagem, ensinando o aluno a tomar um único eixo e fazer a rotação do sólido, o que também facilitará a contagem.

O conceito de faces, vértices e arestas é visto pela primeira vez no sexto ano do ensino fundamental; depois, é visto indiretamente quando se trabalha volume, no oitavo ano, e enfim, é estudado de forma mais completa no segundo ano do ensino médio.

E é nesse momento que entra o estudo da geometria espacial, apenas no segundo ano do ensino médio. Por essa razão é importante rever esses conceitos para relembrá-los, de forma que fique claro, facilitando o estudo dos assuntos posteriores.

Outra atividade simples, porém rica, é pedir para que eles marquem as arestas do poliedro. Alguns alunos irão marcar os lados dos polígonos que formam as faces, ou seja, farão duas marcas em cada aresta. Assim, podemos ver claramente qual aluno ainda não compreendeu o conceito.

Construir "esqueletos" de poliedros também é uma boa atividade para fixação do conceito de vértices e arestas. Foi feita com eles apenas a construção do "esqueleto" de um tetraedro, por ser o mais fácil de montar e suficiente para o objetivo, que era fechar essa parte de conceituação de vértices e arestas. Para isso, além de explicar o passo a passo da montagem, foi utilizado um vídeo que pode ser encontrado em http://www.uff.br/cdme/poliedros_platao_dual/aluno02.html.

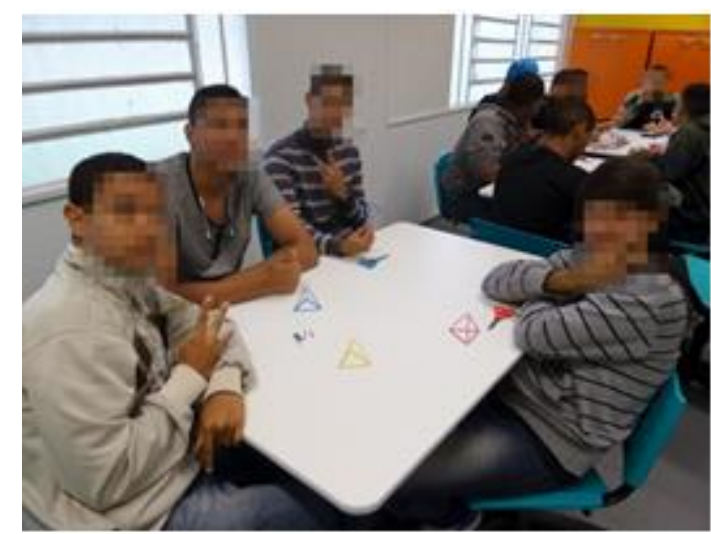

Figura 54 - Produção do esqueleto do tetraedro. Fonte: da autora 
A construção é feita com canudinhos e a quantidade utilizada é o número de arestas do poliedro, pois cada canudinho representa uma aresta.

A atividade permite trabalhar também o conceito de regularidade de um poliedro, frisando a importância de os canudinhos serem cortados do mesmo tamanho, pois trata-se de um poliedro regular e ter todas as arestas congruentes é uma característica.

Para contar os vértices, utilizamos massa de modelagem para fazer o acabamento da construção, colocando-a no encontro das arestas, evidenciando os vértices.

Esses três assuntos foram tratados durante as três primeiras construções, tetraedro, octaedro e icosaedro respectivamente.

Antes de iniciar a construção do hexaedro (ou cubo), foi pedido que eles fizessem uma tabela com o nome dos poliedros já montados, o número de faces, vértices e arestas de cada um deles e conforme fossem construindo os outros poliedros iriam completando. Além disso, foi solicitado que relacionassem o número de arestas com o número de faces e com o número de vértices, separadamente. Os dados colocados na tabela e os poliedros em mãos para observação facilitam a compreensão dessa relação. Nesse momento foi lançado um desafio e o passo seguinte foi uma atividade complementar. A atividade foi de observação e registro, a construção de uma segunda tabela onde eles anotavam os tipos de face de cada poliedro e número de arestas concorrentes a um mesmo vértice.

Com a tabela parcialmente preenchida, foi dada continuidade à construção dos outros dois poliedros de Platão, o hexaedro (ou cubo) e o dodecaedro. Conforme o número de faces dos poliedros construídos foi aumentando, alguns sentiram dificuldades em contar as faces, os vértices e as arestas, sem que se perdessem. Mas como tinham o sólido primeiramente planificado, foi sugerido que continuassem a fazer a contagem das faces antes de montarem e utilizarem as relações para determinar o número de arestas e em seguida o número de vértices. Logo após, foi apresentada a eles a fórmula de Euler para poliedros convexos:

$$
V+F=A+2
$$


Cada aluno construiu os cinco Poliedros de Platão e o passo seguinte foi entender por que só existem cinco.

Levar aos alunos demonstrações formais que encontramos nos livros não iria chamar muito a atenção da maioria e seria mais difícil alcançar a compreensão de todos, pois não é algo comumente trabalhado em sala. E como o foco do trabalho era tornar o conteúdo mais atrativo de forma que despertasse no aluno o interesse em aprender, foi feita uma demonstração através da construção de poliedros regulares, onde se concluiu que só é possível construir os cinco estudados até o momento. Foi desenvolvido um vídeo com essa demonstração, para ser utilizado posteriormente na terceira etapa do trabalho e para que se tivesse 0 conteúdo acessível na rede. Vide https://www.youtube.com/watch?v=tjcbL6Rb4z8.

O material utilizado para tal demonstração nos permite montar poliedros com faces de mais de um tipo de polígono e a partir daí começou-se a falar sobre os poliedros semirregulares, mais especificamente dos Poliedros de Arquimedes.

Mais eficiente do que apenas colocar a definição de Poliedros semirregulares no quadro foi poder visualizar o que estava sendo estudado. Começou-se então a montar os Poliedros Arquimedianos, julgados em ordem crescente de dificuldade.

Inicialmente, com a construção do tetraedro truncado, os alunos já estavam cientes de como podem ser obtido alguns Poliedros de Arquimedes, então, era deixado por conta deles dizer a partir da secção de qual Poliedro de Platão obtinha-se tal poliedro.

Continuando a completar a tabela, foi questionado se a fórmula de Euler dada anteriormente também era válida para tais poliedros e deixado que eles avaliassem. Alguns rapidamente disseram que não funcionava, pois não conseguiam usar a fórmula, já que o poliedro possuía faces de mais de um tipo; outros apostaram positivamente, porém vieram buscar auxílio na utilização da fórmula. Então, foi pedido para que analisassem os poliedros, como já feito anteriormente, e tentassem relacionar o número de arestas com o número de faces. E a partir do que já tinha sido visto antes, foi apresentada a fórmula que dava essa relação também para poliedros semirregulares e que auxilia na utilização da 
fórmula de Euler. Onde A é o número de arestas do poliedro, $\mathrm{N}$ é o número de lados do polígono que forma a face e F é o número de faces do poliedro.

$$
A=\frac{N \times F}{2}
$$

Apesar da fórmula de Euler ser válida também para alguns poliedros não convexos, apenas foi comentada em nível de informação extra, deixando-se claro que seriam apenas exceções e também, por esse motivo, o foco seria na utilização para os convexos.

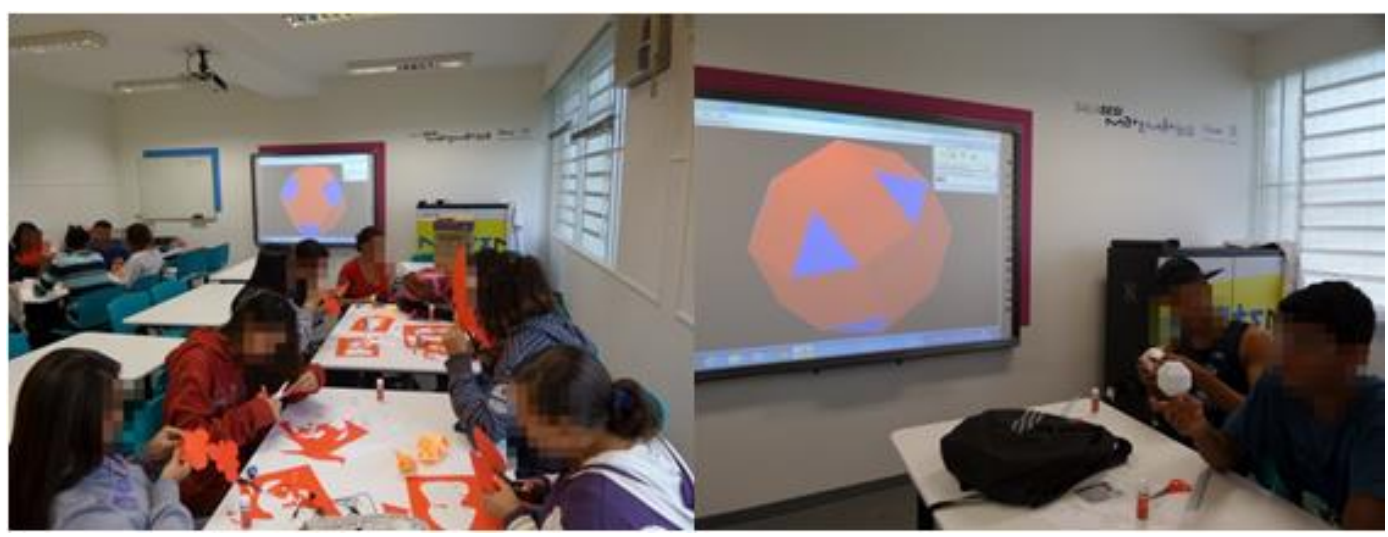

Figura 55 - Alunos produzindo poliedros Arquimedianos. Fonte: da autora

Após a construção dos treze poliedros de Arquimedes foi destacado cada tipo de face, pintando com cores diferentes.

Uma construção que despertou muita curiosidade foi a do icosaedro truncado, que é o modelo das bolas das Copas do Mundo de Futebol dos anos de 1970, 1974, 1978, 1982, 1986, 1990, 1994, 1998 e 2002. Sendo as de 1970 e 1974 melhor visualizadas, pois os gomos pentagonais são pretos e os hexagonais são brancos. E assim foi feito o icosaedro truncado, já com a planificação em preto e branco. Foi montado também um icosaedro truncado um pouco maior para que fosse feita uma experiência em sala. Encheu-se uma bexiga de aniversário dentro dele até que tomasse um formato arredondado semelhante a uma bola. 


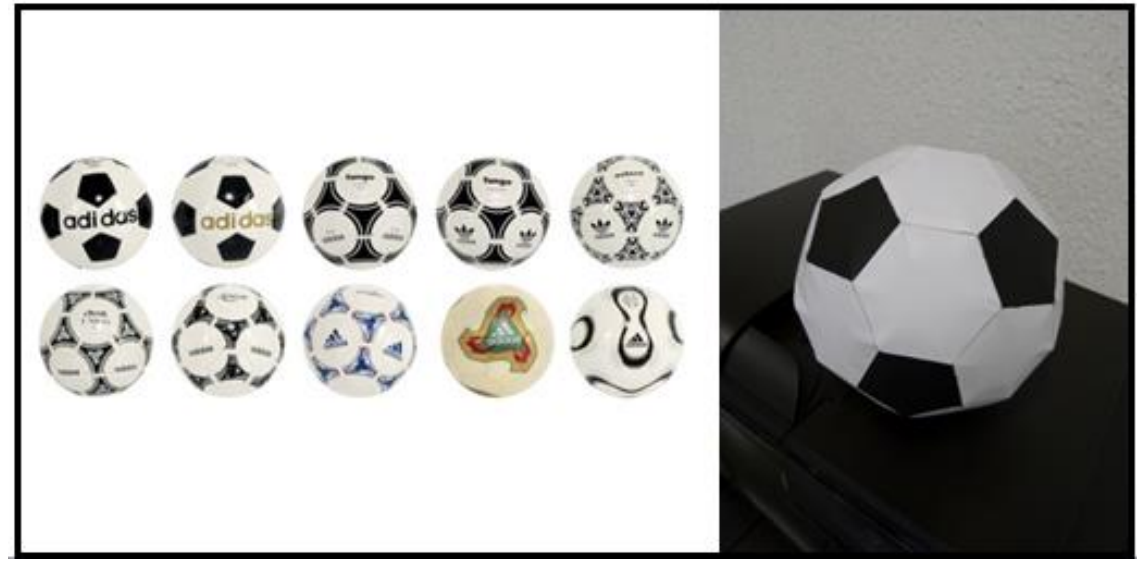

Figura 56 - Modelos da bola das Copas do Mundo de Futebol.

Fonte: http://blogs.diariodepernambuco.com.br/esportes/2010/04/23/a-copa-domundo-na-sua-estante/

\subsubsection{Segunda etapa}

Esta etapa foi principalmente de exposição, que aconteceu na Segunda Mostra Cultural da escola, onde foi exibido para todos os presentes o resultado de um trabalho minucioso e rico em conteúdo. Porém, o foco nesse momento foi apresentar de forma rápida, sucinta e atraente aos olhos dos espectadores, os Poliedros de Arquimedes.

O trabalho foi muito visitado, encantou professores de todas as áreas e alguns professores de matemática chegaram a relatar que não tinham conhecimento de tais poliedros.

A exposição foi composta por um quadro com os Poliedros de Platão e os Poliedros de Arquimedes correspondentes às secções. Ao lado, mais detalhadamente, estava exposto cada poliedro com seu nome, número de faces, vértices e arestas. No caso dos Arquimedianos, o número de faces era específico a cada tipo. 


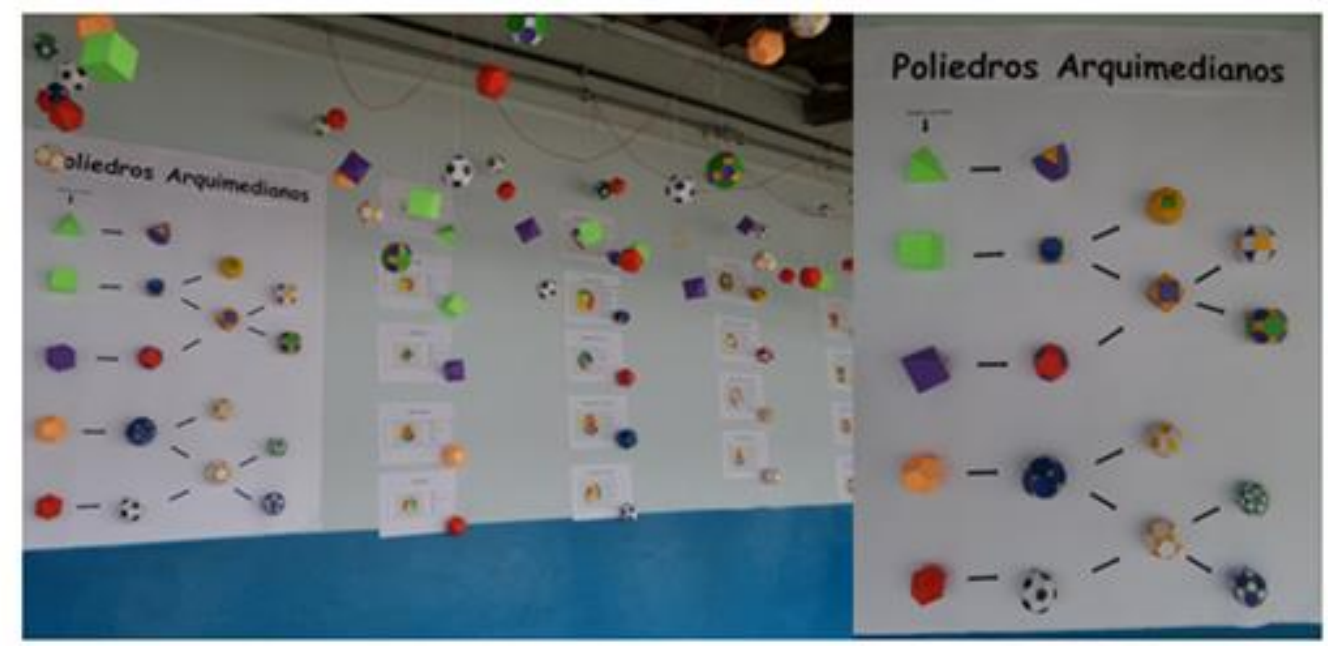

Figura 57 - Exposição do trabalho na Mostra Cultural da escola.

Fonte: da autora

Um trabalho nessas proporções tem muitas finalidades, a começar pelo reconhecimento do trabalho dos alunos. Eles com todo empenho, foram

fundamentais para tal resultado. E nada melhor do que esse prestígio para que eles se sintam importantes, além de trabalhar o contato social, o respeito ao próximo e a atribuição de responsabilidades.

Introduzir um conteúdo através da arte é uma forma de se desenvolver uma aula criativa, que busca um novo olhar daquele aluno desinteressado, que desperta o querer conhecer e aprender. É uma aula desenvolvida com intuito de ultrapassar a barreira das limitações de cada aluno.

Construir uma nova relação de ensino e aprendizagem sobre outras bases cognitivas e afetivas é um desafio complexo e urgente, uma vez que educar não é repetir regras e memorizar técnicas, mas sim criar ideias e encantar.(NUNES, 2006, p.10)

O trabalho tanto alcançou o planejado que a escola foi convidada a expô-lo na primeira feira da Metropolitana II. Foi então que decidiu-se que a terceira etapa aconteceria lá, com a vantagem de abranger um público muito maior do que o planejado. Isso assustou um pouco os alunos, pois estariam ao lado de 49 escolas do município de São Gonçalo, RJ, onde eles teriam que lidar com pessoas desconhecidas. 


\subsubsection{Terceira Etapa}

Em quatro anos de profissão este foi o primeiro trabalho desenvolvido com esta abrangência e por isso, alunos e professora estavam bastante apreensivos. A tenda não comportava a todos os alunos, então foi preciso fazer um rodízio de pessoas de forma que em nenhum momento ficasse vazia ou com um número insuficiente para atender aos visitantes.

O vídeo produzido com a explicação do porquê da existência de apenas cinco Poliedros de Platão ficou sendo reproduzido durante todo evento. Os alunos iam explicando para os visitantes ao mesmo tempo em que ensinavam a construir os poliedros e, por fim, deixavam que eles escolhessem um dos poliedros para montar e levar.

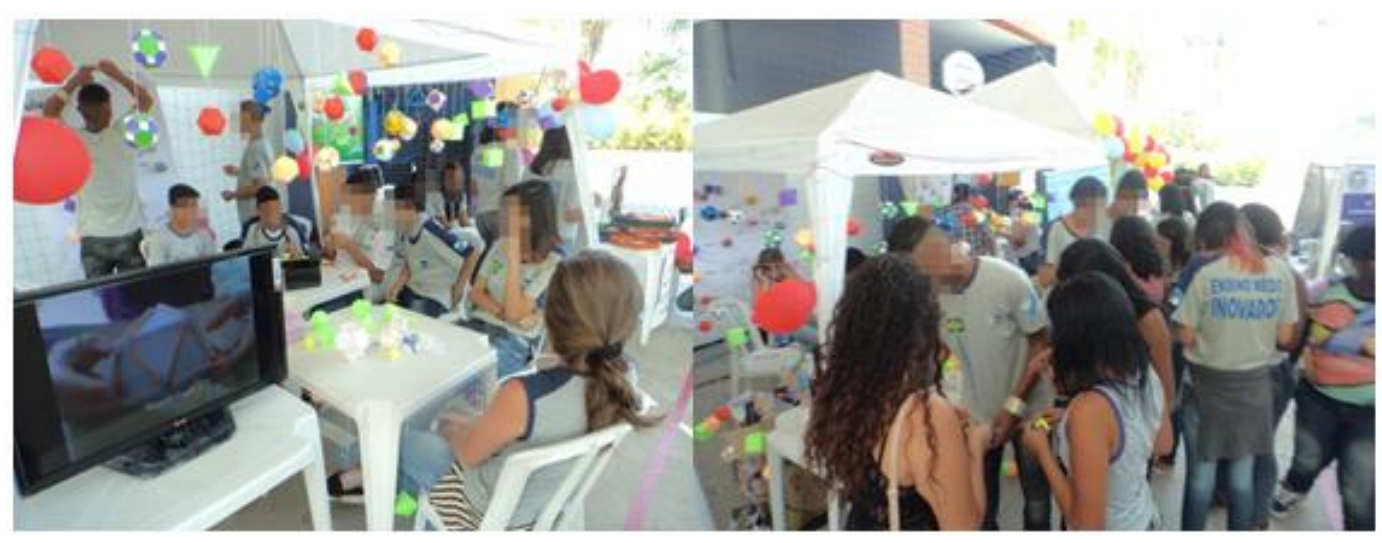

Figura 58 - O trabalho na Feira da Metropolitana II. Fonte: da autora

Inicialmente os alunos estavam tímidos, porém, bastou o primeiro passo e tudo fluiu muito bem. Eles surpreenderam em tudo: organização, trabalho em equipe, atenção com o público e desenvolvimento da atividade.

A satisfação do público foi visível pela quantidade de visitantes, no interesse que eles apresentavam durante o desenvolvimento da atividade e ao final quando saíam admirados com seus poliedros, montados por eles mesmos. 


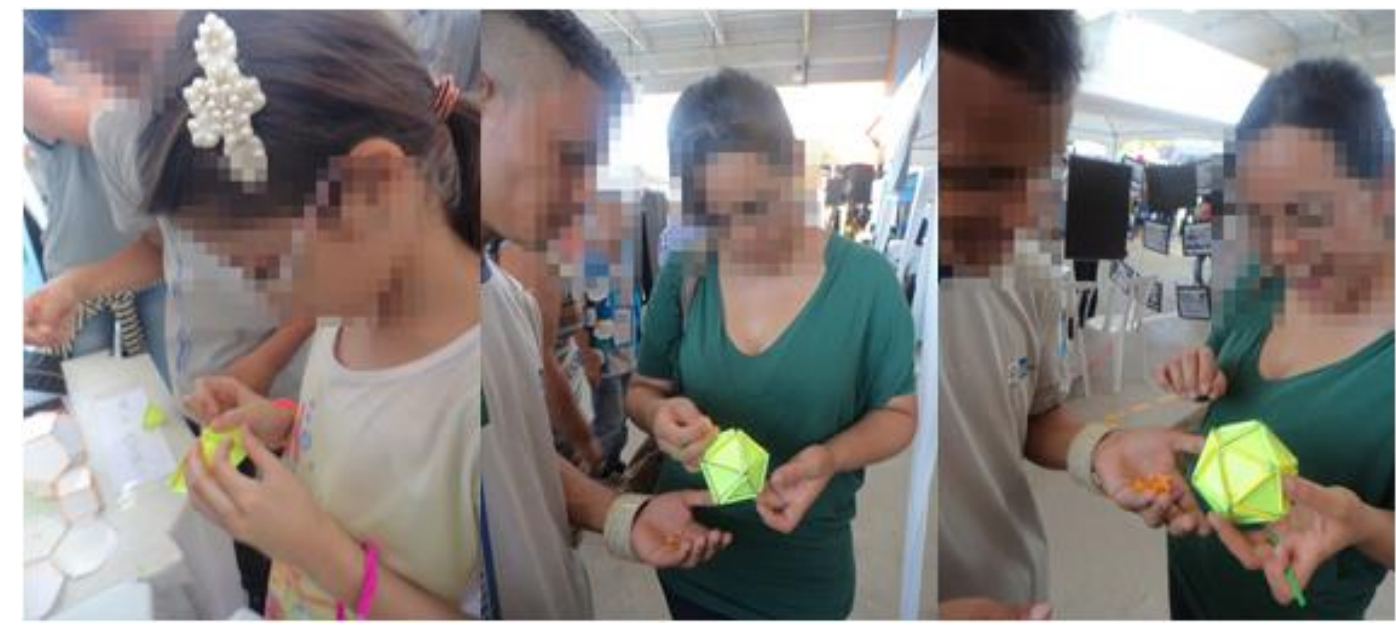

Figura 59 -O Público atraído pelo trabalho.

Fonte: da autora

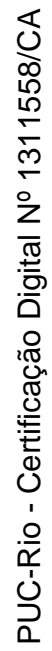




\section{CONSIDERAÇÕES FINAIS}

A escolha da geometria espacial como objeto de estudo se deu pela admiração na riqueza do que pode ser desenvolvido dentro do conteúdo trabalhado e pelo interesse no aprofundamento do estudo de assuntos não tratados durante a vida acadêmica.

Foi observado que ao se escolher um tema para estudo, o mesmo oferece mais do que se espera em termos de aprendizagem. Ao mesmo tempo, tem-se uma pequena ideia de trabalho a ser desenvolvido e este começa a expandir-se meio às ideias que surgem durante o processo de pesquisa.

Espera-se que este trabalho venha contribuir na vida profissional de outros professores, principalmente daqueles que não acreditam que se pode desenvolver um trabalho dentro de condições supostamente limitadas. Pois este foi exemplo de um projeto que superou expectativas no que diz respeito a ter uma resposta positiva dos alunos. O trabalho foi realizado em conjunto e a ideia de trabalhar em equipe foi reforçada a cada encontro. As metas semanais e prazos para cada uma das três etapas se constituíram como forma de atribuição de responsabilidade aos alunos.

“[...] um importante recurso para o desenvolvimento das competências é o trabalho em grupo (BRASIL, p. 129)"

Na última etapa, como feedback do trabalho realizado, pôde-se ver os alunos colocando em prática o que aprenderam, seguros do que estavam fazendo, lidando com pessoas fora do ambiente deles, ultrapassando a barreira da timidez, aumentando sua autoestima e desenvolvendo um excelente trabalho em grupo. 


\section{REFERÊNCIAS BIBLIOGRÁFICAS}

ALMEIDA, Talita Carvalho S. Sólidos arquimedianos e cabri 3D: um estudo de truncaturas baseadas no renascimento. 2010. Dissertação (Mestrado Profissional em Matemática) - Pontifícia Universidade Católica de São Paulo, São Paulo. Disponível em: $<$ http://www.sapientia.pucsp.br/tde_busca/arquivo.php? codArquivo=10963 > . Acesso em: 15 fev. 2015.

AZAMBUJA FILHO, Zoroastro. Demonstração do teorema de Euler para poliedros convexos. Revista do Professor de Matemática, São Paulo, n. 3, p. $1-4, \quad 2010 . \quad$ Disponível em: <http://www.ime.usp.br/ pleite/pub/artigos/elon/rpm3.pdf>. Acesso em: 15 fev. 2015.

BRASIL. Ministério da educação. Orientações educacionais complementares aos parâmetros curriculares nacionais: ciências da natureza, matemática e suas tecnologias. Brasília, 2006.

CROWELL, Peter R. Polyhedra. Cambridge: Cambridge University Press, 1997.

DOLCE, Osvaldo; POMPEO, José Nicolau. Fundamentos da matemática elementar: geometria plana. 7. ed. São Paulo: Atual, 1993. v. 9.

Fundamentos da matemática elementar: geometria plana. 5.ed. São Paulo: Atual, 1993.

FAINGUELERNT, Estela Kaufman; NUNES, Katia Regina Ashton A. Fazendo artecom a matemática. Porto Alegre: Artmed, 2006.

GRUNBAUM, Branko. An enduring error. Elemente der Mathematik, Washington, v. 64, n. 3, p. 89-101, 2009. Disponível em: $<$ http://www.ems-ph.org/journals/show_ abstract.php?issn $=0013$ 6018\&vol=64\&iss=3\&rank=1>. Acesso em: 15 fev. 2015.

HISTÓRIAS da Geometria. Disponível em: <http://www.apm.pt/apm/amm/ paginas/231_249.pdf>. Acesso em: 15 fev. 2015.

KALEFF, Ana Maria Martensen Roland. Novas tecnologias no ensino da matemática: tópicos em ensino de geometria. Rio de Janeiro: Fundação CECIERJ, 2008. 
LIMA, Elon Lages; CARVALHO, Paulo Cezar Pinto; WAGNER, Eduardo; MORGADO, Augusto César. A matemática do ensino médio. 6. ed. Rio de Janeiro: SBM, 2006. v. 2.

MUNIZ NETO, Antonio Caminha. Tópicos de matemática elementar: geometria euclidiana plana. Rio de Janeiro. SBM, 2012. v. 2

RIO DE JANEIRO. Secretaria Estadual de Educação. Currículo mínimo: matemática. Rio de Janeiro, 2012. Disponível em: $<$ http://www.conexaoprofessor.rj.gov.br/curriculo_aberto.asp>. $15 \mathrm{fev}$. 2015.

SOLER, Gregoria Guillen. Poliedros. Madrid: Sintesis, 2007.

WENNINGER, Magnus J. Polyhedron models for the classroom. $2^{\text {nd }}$. New York: National Council of Teachers of Mathematics, 1975.

WENNINGER, Magnus J. Polyhedron models. Cambridge: Cambridge University Press, 1974. 